ANDRZEJ SZEPTYCKI

Uniwersytet Warszawski, Narodowy Uniwersytet Doniecki im. Wasyla Stusa w Winnicy ORCID: 0000-0003-2729-6967

andrzej.szeptycki@uw.edu.pl

\title{
Stan badań nad współczesnymi stosunkami polsko-rosyjskimi
}

The state of research on contemporary Polish-Russian relations

Słowa kluczowe:

Polska, Rosja, stosunki międzynarodowe, stan badań
Keywords:

Poland, Russia, international relations, state of research 


\section{The state of research on contemporary Polish-Russian relations}

The analysis of the state of research on contemporary Polish-Russian relations leads to the conclusion that this topic has been undertaken by the representatives of various fields of social sciences in Poland and Russia, as well as in the West for over last three decades. At the same time, no publications describe it in a comprehensive and up-to-date manner. This is due to the complex nature of the mutual relations and their high dynamics, as well as the selective approach of researchers. Currently, most of the works are endogenous: Polish authors write for Polish readers, and Russian researchers - for the Russian audience. Paradoxically, the most popular works devoted to Poland and Russia - although it is difficult to judge $a$ priori whether or not they are the best - have been published in Western countries. Moreover, most of the texts devoted to Polish-Russian relations, especially in the political sphere, are devoid of theoretical apparatus. Certain idées fixes present in the literature, such as the imperialist nature of contemporary Russian policy, the resulting threats to Poland and Polish Russophobia deserve an in-depth analysis. Researchers should also pay more attention to some issues that are currently mainly dealt with by experts and journalists - in particular, the Russian hybrid war and whether Poland is or can be its target, as well as possible Russian interference in political life in Poland since 2014. 


\section{Wprowadzenie*}

tosunki polsko-rosyjskie budzą zainteresowanie z czterech powodów. $\mathcal{P}$ Po pierwsze, z uwagi na trudną historię, której przykładami są wygnanie przez Rosjan z Kremla sił I Rzeczypospolitej w 1612 r. czy bitwa warszawska z roku 1920, podczas której wojsku polskiemu udało się odeprzeć pochód bolszewików na zachód; rocznice tych wydarzeń obchodzone są jako święta narodowe odpowiednio w Rosji i Polsce. Po drugie, z powodu odmiennych modeli transformacji ustrojowej, jakie obrały oba te państwa po upadku komunizmu i rozpadzie zSRR. Po trzecie, ze względu na to, że w istotnym stopniu mają charakter konfliktowy. Wynika to w szczególności z asymetrycznego charakteru dwustronnych relacji i konkretnych problemów, które dzielą Polskę i Rosję: konfliktu pamięci historycznych wynikającego z odmiennej interpretacji wspólnej przeszłości, zwłaszcza wydarzeń drugiej wojny światowej, członkostwa Polski w NATO i jego charakteru, polityki energetycznej, sprzecznych wizji wspólnego sąsiedztwa itd. ${ }^{1}$ Po czwarte wreszcie, ponieważ wzajemne postrzeganie się obu państw i społeczeństw jest negatywne. Część ekspertów i środowisk politycznych nad Wisłą uważa politykę Federacji Rosyjskiej za bezpośrednie zagrożenie dla Polski. Znajduje to odzwierciedlenie w nastrojach społecznych: wedle danych z 2020 r. niechętnie odnosi się do Rosji 59 proc. ankietowanych Polaków². Rosyjskie elity rządzące dążą do umocnienia legitymizacji swojej władzy poprzez kreowanie rzekomego zewnętrznego zagrożenia, w rezultacie czego Polska konsekwentnie zaliczana jest przez badanych do pięciu głównych wrogów kraju ${ }^{3}$.

Celem niniejszego artykułu jest analiza obecnego stanu wiedzy nad współczesnymi stosunkami polsko-rosyjskimi. Zagadnienie to - inaczej niż

* $\quad$ Praca powstała w wyniku realizacji projektu badawczego nr 2020/39/B/HS5/00782 finansowanego ze środków Narodowego Centrum Nauki.

1 K. Pełczyńska-Nałęcz, Stosunki polityczne między Polska a Rosja po 1990 r., [w:] Białe plamy, czarne plamy. Sprawy trudne w relacjach polsko-rosyjskich (1918-2008), red. A. D. Rotfeld, A.W. Torkunow, Polski Instytut Spraw Międzynarodowych, Warszawa 2010, s. 669-688; A. W. Malgin, Stosunki polityczne między Polską a Rosja po 1990 r., [w:] Białe plamy, czarne plamy..., s. 689-717.

2 Topline questionnaire. Pew Research Center Spring 2019 Global Attitudes survey, Pew Research Center, 7 II 2020, s. 4: <https://www.pewresearch.org/wp-content/uploads/ 2020/o2/Views-of-Russia-Topline-for-Release_UPDATED.pdf $>$ [dostęp: 19 XI 2020].

3 Enemies, „Levada-Center” [online], 5 XI 2020 [dostęp: 19 XI 2020]: <https://www. levada.ru/en/2020/11/o5/enemies-2/>. 
w przypadku relacji polsko-radzieckich ${ }^{4}$ - nie było do tej pory przedmiotem pogłębionych dociekań. Wyjątkiem są polskie prace na temat stanu badań nad obwodem kaliningradzkim ${ }^{5}$. Ramy czasowe tekstu obejmują zasadniczo lata 1990-2020. Wybór dolnej granicy wynika z dwu powodów. Po pierwsze, w czerwcu 1990 r. Rosyjska Federacyjna SRR proklamowała suwerenność (w przeciwieństwie do innych republik związkowych Rosja nie ogłosiła niepodległości). Po drugie, w tym samym roku Polska zainicjowała politykę dwutorowości wobec wschodniego sąsiedztwa zakładającą utrzymanie i rozwój stosunków zarówno z ZSRR jako całością, jak i z niektórymi republikami. Okazjonalnie analizowane będą również badania dotyczące wcześniejszego okresu, zwłaszcza gdy dotyczą wpływu przeszłości na współczesne stosunki polsko-rosyjskie, w szczególności pamięci historycznej Polaków i Rosjan oraz polityki historycznej obu państw. Stosunki międzynarodowe można postrzegać redukcjonistycznie, sprowadzając je do państw, ich interesów, wzajemnych interakcji i następstw dla systemu międzynarodowego, lub holistycznie, przyjmując, że uczestniczą w nich zarówno aktorzy państwowi, jak i niepaństwowi ${ }^{6}$. W niniejszym artykule analizowane będą badania poświęcone współczesnym relacjom polsko-rosyjskim w tym drugim ujęciu.

Aby zrealizować tak zdefiniowany cel, przeanalizowano kolejno uwarunkowania badań nad współczesnymi stosunkami polsko-rosyjskimi, przedstawiono ich ogólną charakterystykę ze szczególnym uwzględnieniem specyfiki na tle nauki o stosunkach międzynarodowych i innych nauk społecznych, zidentyfikowano główne ośrodki i kierunki badań, wskazując też wreszcie możliwe kierunki dalszych studiów w tym obszarze.

Analiza przeprowadzona została $\mathrm{w}$ oparciu o istniejącą literaturę przedmiotu. Są to najczęściej publikacje wydane w Polsce, dlatego właśnie im

4 Zob. np.: W. Materski, Historiografia stosunków polsko-radzieckich. Stan obecny i perspektywy badawcze, "Acta Universitatis Lodziensis. Folia Historica” 1996, nr 55 , s. 15-26; M. Kornat, Stan badań na temat stosunków polsko-radzieckich, [w:] Białe plamy, czarne plamy..., s. 793-841; I. Jażborowskaja, Stan badań na temat stosunków polsko-radzieckich, [w:] Białe plamy, czarne plamy..., s. 842-875.

5 Zob. np. A. Żukowski, Obwód Kaliningradzki Federacji Rosyjskiej jako przedmiot zainteresowania polskich badaczy stosunków międzynarodowych, [w:] Wschód w globalnej $i$ regionalnej polityce międzynarodowej, red. A. Bartnicki, E. Kużelewska, Wydawnictwo „Adam Marszałek”, Toruń 2009, s. 247-260.

6 T. Łoś-Nowak, Stosunki międzynarodowe. Teorie - systemy - uczestnicy, Wrocław 2000, s. 35 . 
poświęcono w tekście najwięcej miejsca. Zarazem należy jednak już na wstępie zauważyć, że najbardziej poczytne prace dotyczące analizowanego zagadnienia pochodzą spoza obu zainteresowanych państw - powstały bowiem na uczelniach anglosaskich. Podczas kwerendy przeprowadzonej w szczególności w bazach Scopus, EBSCO, Google Scholar i rosyjskiej Elektronicznej Bibliotece Naukowej $^{7}$ zidentyfikowano 487 publikacji naukowych dotyczących stosunków polsko-rosyjskich, tak jak zostały one wcześniej zdefiniowane. Trzeba podkreślić, że w niniejszym artykule przywołano tylko niektóre z tych publikacji, a przedstawione dane (zwłaszcza ilościowe) i wnioski powstały w oparciu o całą przeanalizowaną literaturę przedmiotu ${ }^{8}$. Zaliczone zostały do niej książki, artykuły naukowe i rozdziały w pracach zbiorowych; nie uwzględniono natomiast prac niepublikowanych (dysertacji doktorskich czy referatów prezentowanych na konferencjach). Przedmiotem analizy nie były również materiały źródłowe ${ }^{9}$, w szczególności dokumenty (archiwa) i ich zbiory ${ }^{10}$, wspomnienia ${ }^{11}$ czy materiały prasowe.

Istotną kwestią jest zakres tematyczny publikacji mających być przedmiotem analizy. Nie ulega wątpliwości, że powinny zostać uwzględnione teksty dotyczące wprost wspomnianej problematyki lub wybranych jej aspektów (polsko-rosyjskich stosunków politycznych, gospodarczych itd.). Trudniej jest w przypadku prac, które nie dotyczą expressis verbis relacji polsko-rosyjskich. Literatura na temat polityki zagranicznej Rosji jest obszerna, co wynika z pozycji tego państwa na arenie międzynarodowej, ale autorzy wielu publikacji nie podejmują się pogłębionej analizy stosunków

7 "Scopus” [online, dostęp: 10 XII 2020]: <https://www.scopus.com/search/form.uri? display=basic\#basic ; „EBSCO” [online, dostęp: 10 XII 2020]: 〈https://www.ebsco. com/>; "Google Scholar" [online, dostęp: 10 XII 2020]: <https://scholar.google. com/>; „Naučnaâ èlektronnaâ biblioteka” [online, dostęp: 10 XII 2020]: <https:// www.elibrary.ru/defaultx.asp >.

8 Pełna lista analizowanych publikacji dostępna jest w internecie: A. Szeptycki, Stan badań nad wspótczesnymi stosunkami polsko-rosyjskimi, „Repozytorium Otwartych Danych" [online], 2 XII 2020 [dostęp: 3 XII 2020]: 〈https://doi.org/10.18150/ICFU71〉.

9 A.J.Chodubski, Wstęp do badań politologicznych, Wydawnictwo Uniwersytetu Gdańskiego, Gdańsk 2004, s. 103.

10 Polska - Rosja: traktat o przyjaznej $i$ dobrosąsiedzkiej wspótpracy podpisany przez prezydentów Lecha Wałęsę i Borysa Jelcyna dnia 22 maja 1992 w Moskwie oraz inne dokumenty, Polski Instytut Spraw Międzynarodowych, Warszawa 1992.

11 J. Sadecki, J. Bahr, Ambasador, Warszawa 2013 (Biblioteka Gazety Wyborczej). 
Federacji Rosyjskiej z Polską ${ }^{12}$ W przypadku tekstów dotyczących polityki zagranicznej Polski sytuacja przedstawia się odmiennie: jest ich mniej, natomiast relatywnie częściej podejmują kwestię relacji polsko-rosyjskich. Istnieją wreszcie określone obszary badawcze, $\mathrm{w}$ których zagadnienie to podejmowane jest szczególnie często: w przypadku Rosji dotyczy to zwłaszcza polityki państwa wobec Unii Europejskiej, a w szczególności członków Grupy Wyszehradzkiej; w przypadku Polski istotną rolę odgrywają natomiast publikacje dotyczące jej polityki wschodniej.

\section{Uwarunkowania historyczne i strukturalne}

Pierwsze próby pogłłębionej refleksji nad stosunkami polsko-rosyjskimi datują się na koniec XVIII w. W Uwagach nad rządem polskim z $1772 \mathrm{r}$. Jean-Jacques Rousseau przestrzegał Polaków przed ingerencją Rosji $\mathrm{w}$ wewnętrzne sprawy ich państwa i podkreślał znaczenie polskiej tożsamości jako przeszkody dla imperialnej polityki wschodniego sąsiada ${ }^{13}$.

Do wzrostu znaczenia tej tematyki w XIX w. przyczyniły się włączenie części ziem I Rzeczypospolitej do imperium rosyjskiego w wyniku rozbiorów oraz przebudzenie narodowe w Europie Środkowej i Wschodniej. W okresie zaborów polskie elity w kraju i na emigracji szukały najlepszych rozwiązań dla podzielonego przez trzy ościenne mocarstwa narodu. Do wyboru miały walkę zbrojną, lojalność wobec zaborców lub pracę organiczną ${ }^{14}$, a w późniejszym czasie - wobec narastających rozbieżności między tymi ostatnimi - stanęły przed koniecznością opowiedzenia się po stronie jednego z imperiów. Rosja - w istotnym stopniu pod wpływem powstania listopadowego z lat 1830-1831 - podjęła

12 Zob. np.: R. H. Donaldson, J. L. Nogee, The foreign policy of Russia. Changing systems, enduring interests, M. E. Sharpe, London-Armonk 2005; Polityka zagraniczna Rosji, red. S. Bieleń, M. Raś, Wydawnictwo „Difin”, Warszawa 2008; K. Malak, Czynnik wojskowy w polityce zagranicznej Federacji Rosyjskiej (1991-200o), Akademia Obrony Narodowej, Warszawa 2001; A. Bryc, Rosja w XXI wieku. Gracz światowy czy koniec gry?, Wydawnictwa Akademickie i Profesjonalne, Warszawa 2008.

13 J. J. Rousseau, Uwagii nad rządem Polski, Krakowska Spółka Wydawnicza, Kraków 1924, s. 10, 12, 99.

14 P. Samuś, Wasza kartka wyborcza jest silniejsza niż karabin, niż armata. Z dziejów kultury politycznej na ziemiach polskich pod zaborami, Wydawnictwo Uniwersytetu Łódzkiego, Łódź 2013. 
działania na rzecz rusyfikacji wielonarodowego państwa ${ }^{15}$. Zarówno ten, jak i kolejny polski zryw niepodległościowy w 1863 r. odegrały istotną rolę w rosyjskiej debacie nad miejscem Cesarstwa w Europie i próbami jego unowocześnienia ${ }^{16}$. Problematyką Polski i Rosji oraz ich wzajemnymi relacjami (w szerokim tego słowa znaczeniu) zajmowali się wówczas przede wszystkim pisarze, historycy i działacze polityczni: po stronie polskiej m.in. Adam Mickiewicz, Joachim Lelewel, Henryk Kamieński, a później Józef Piłsudski czy Roman Dmowski, po stronie rosyjskiej zaś np. Nikołaj Karamzin, Aleksander Puszkin, Aleksander Hercen, Włodzimierz Sołowjow i Siergiej Sołowjow ${ }^{17}$.

Nowy etap w historii badań nad wzajemnymi relacjami rozpoczął się wraz z końcem pierwszej wojny światowej, która zaowocowała rewolucją bolszewicką w Rosji i odrodzeniem państwa polskiego. W Polsce zaczęła się wówczas rozwijać nauka o stosunkach międzynarodowych ${ }^{18}$. Podjęto systematyczne prace badawcze nad Związkiem Radzieckim, m.in. w Instytucie Naukowo-Badawczym Europy Wschodniej utworzonym w 1930 r. w Wilnie. W tym kontekście na uwagę zasługują w szczególności prace Mariana Zdziechowskiego, Feliksa Konecznego, Stanisława Swianiewicza czy Adolfa Bocheńskiego ${ }^{19}$. Zainteresowanie Związkiem Radzieckim miało wymiar nie tylko naukowy, ale i praktyczny. Polska dążyła do wsparcia procesów narodowościowych w granicach ZSRR i rozsadzenia tego państwa od środka; polityka ta zyskała nazwę prometeizmu ${ }^{20}$.

15 L. Bazylow, P. Wieczorkiewicz, Historia Rosji, Zakład Narodowy im. Ossolińskich, Wrocław-Warszawa-Kraków 2005, s. 216.

16 Wbrew królewskim aliansom. Rosja, Europa i polska walka o niepodległość w XIX w., red. Ł. Adamski, S. Dębski, Centrum Polsko-Rosyjskiego Dialogu i Porozumienia, Warszawa 2016.

17 Zob. obszerną antologię: Dusza polska i rosyjska. Od Adama Mickiewicza i Aleksandra Puszkina do Czesława Miłosza i Aleksandra Solżenicyna. Materiały do „katalogu” wzajemnych uprzedzeń Polaków i Rosjan, red. A. de Lazari, Polski Instytut Spraw Międzynarodowych, Warszawa 2004. Zob. także pracę zbiorową poświęconą publikacjom większości wspomnianych autorów: Myślą i słowem. Polsko-rosyjski dyskurs ideowy XIX wieku, red. Ł. Adamski, S. Dębski, Centrum Polsko-Rosyjskiego Dialogu i Porozumienia, Warszawa 2014.

18 J. Czaputowicz, K. Ławniczak, A. Wojciuk, Nauka o stosunkach międzynarodowych i studia europejskie w Polsce, Wydawnictwo Naukowe "Scholar", Warszawa 2015, s. 36.

19 R. Pipes, Polska sowietologia do 1939 roku, „Studia nad Autorytaryzmem i Totalitaryzmem" 2011, t. 33, s. 33-45.

20 J. J. Bruski, Między prometeizmem a Realpolitik. II Rzeczpospolita wobec Ukrainy Sowieckiej 1921-1926, Historia Iagellonica, Kraków 2010. 
Końcowy okres caratu i pierwsze lata po rewolucji bolszewickiej charakteryzowały się ograniczoną wprawdzie, ale jednak wolnością słowa, co umożliwiło rozwój refleksji na temat Polski i Rosji (należy tu wspomnieć twórczość Władimira Erna, Wiaczesława Iwanowa i Nikołaja Bierdiajewa). Od połowy lat trzydziestych nauka i kultura zostały poddane w ZSRR ścisłej kontroli totalitarnego państwa, a ich przedstawiciele doświadczyli masowych represji ${ }^{21}$. Publikacje poświęcone Polsce i relacjom polsko-radzieckim miały w większości charakter propagandowy lub czysto informacyjny.

Po 1945 r. charakter stosunków dwustronnych uległ zasadniczej zmianie, Polska stała się bowiem państwem uzależnionym od ZSRR ${ }^{22}$. Liczba publikacji na ten temat wzrosła, ale były to często prace silnie zideologizowane, opisowe i pomijające zagadnienia objęte zakazem cenzury (dotyczyło to w szczególności zbrodni katyńskiej). W Polsce zresztą w ogóle nie prowadzono w tym okresie badań sowietologicznych, a nauka o stosunkach międzynarodowych została zdominowana przez koncepcje marksistowskie, co również miało negatywny wpływ na jej dorobek ${ }^{23}$. W ZSRR z kolei nauka ta zaczęła się rozwijać dopiero w okresie postalinowskiej odwilży (wcześniej, bo już w 1944 r. powstał Moskiewski Państwowy Instytut Stosunków Międzynarodowych - MGIMO) ${ }^{24}$. Większą swobodą cieszyli się autorzy emigracyjni, a ważną rolę odgrywały w tym kontekście zwłaszcza paryski Instytut Literacki i wydawany przez niego miesięcznik „Kultura” (Jerzy Giedroyc, Juliusz Mieroszewski), który podjął systematyczną analizę sytuacji w Związku Radzieckim i refleksję na temat potrzeby zbudowania w przyszłości przez Polskę dobrych relacji z państwami, które miały się z niego wyłonićc ${ }^{25}$.

21 M. Heller, A. Niekricz, Utopia u władzy. Historia Związku Sowieckiego, t. 1, Polonia Book Fund, London 1985, s. 238-239.

22 A. Skrzypek, Mechanizmy uzależnienia. Stosunki polsko-radzieckie 1944-1957, Wyższa Szkoła Humanistyczna im. Aleksandra Gieysztora, Pułtusk-Warszawa 2002.

23 J. Czaputowicz, K. Ławniczak, A. Wojciuk, Nauka..., s. 40, 60.

24 M. M. Šumilov, Teoretičeskie osnovy mirovoj politiki i meždunarodnyh otnošenij, [w:] Mirovâ̂ politika i meždunarodnye otnošeniâ, red. Û. Kosov, Izdatel'skij dom „Piter”, Sankt-Peterburg 2011, s. 23.

25 Zob. Kultura - Rosja, t. 1: Literatura rosyjska w kręgu „Kultury”, red. P. Mitzner, Instytut Literacki „Kultura”, Instytut Książki, Paryż-Kraków 2016; Kultura-Rosja, t. 2: „Kultura” i emigracja rosyjska, red. P. Mitzner, Instytut Literacki „Kultura”, Instytut Książki, Paryż-Kraków 2016. 
Tematykę relacji polsko-radzieckich podejmowali również niektórzy emigracyjni autorzy rosyjscy, w szczególności ci związani z „Kulturą", jak Michał Heller $^{26}$. Były one też wreszcie przedmiotem zainteresowania badaczy amerykańskich $^{27}$.

Koniec systemu komunistycznego otworzył nowe perspektywy badawcze przed specjalistami z zakresu stosunków polsko-radzieckich, a od końca 1991 r. - polsko-rosyjskich. Badania te w istotnym stopniu przestały podlegać ograniczeniom polityczno-ideologicznym i cenzurze, przez co możliwe stało się podjęcie prac nad białymi plamami; symboliczne znaczenie miało $\mathrm{w}$ tej kwestii uznanie przez ZSRR odpowiedzialności za zbrodnię katyńską, do czego doszło w kwietniu 1990 r. Ponadto pojawiły się nowe instrumenty internacjonalizacji nauki mające sprzyjać większej mobilności i realizacji wspólnych projektów badawczych ${ }^{28}$. Pewne znaczenie miał też rozwój technologii, zwłaszcza internetu, umożliwiający szerszy dostęp do dorobku nauk społecznych na Zachodzie.

Wciąż jednak nauki społeczne w Polsce i Rosji (w szczególności nauka o stosunkach międzynarodowych) borykają się z istotnymi problemami, które mają negatywny wpływ na badania w zakresie relacji dwustronnych. Poziom nauki w obu krajach nadal znacząco odbiega od tego w wysokorozwiniętych ośrodkach zachodnich: indeks Hirscha w obszarze nauk politycznych i stosunków międzynarodowych wynosi 37 w przypadku Rosji, a $23 \mathrm{w}$ przypadku Polski (w Stanach Zjednoczonych dla porównania $275)^{29}$. Sytuacja taka wynika m.in. z relatywnie niskiego poziomu wydatków na badania i rozwój. Wedle danych z 2018 r. w Rosji wyniosły one 1 proc. PKB, w Polsce - 1,2 proc., a w wiodących wysokorozwiniętych państwach zachodnich $-1,7-3,1$ proc. $^{30}$

26 M. Heller, Polska w oczach Moskwy, Instytut Literacki, Paryż 1984.

27 R. F. Staar, Poland 1944-1962. The sovietization of a captive people, Louisiana State University Press, Baton Rouge 1962.

28 Zob. krytyczną ocenę ich wykorzystania w Polsce: M. Popowska, Internacjonalizacja uczelni wyższych na świecie $i$ jej atrybuty a polska rzeczywistość, „Horyzonty Wychowania" 2016, t. 15, nr 35, s. 131-154.

29 Country Rankings, „Scimago Journal \& Country Rank” [online], kwiecień 2020 [dostęp: 31 VII 2020]: 〈https://www.scimagojr.com/countryrank.php?category=3320 >.

30 Research and development expenditure (\% of GDP), "The World Bank" [online, dostęp: 31 VII 2020]: <https://databank.worldbank.org/reports.aspx? source $=2$ \&series $=$ GB. XPD.RSDV.GD.ZS\&country $=>$. 
Polskie i rosyjskie uczelnie wyższe tylko w ograniczonym zakresie korzystają z instytucjonalnego i finansowego wsparcia obu państw w zakresie współpracy badawczej. Polska Narodowa Agencja Wymiany Akademickiej nie prowadzi programów adresowanych do naukowców chcących odwiedzić Rosję i vice versa. Większą rolę odgrywa Centrum Polsko-Rosyjskiego Dialogu i Porozumienia, które rokrocznie przyznaje stypendia dla badaczy z Rosji; w 2018/2019 r. ufundowało ich 11, w tym 3 na badania dotyczące współczesnych relacji polsko-rosyjskich ${ }^{31}$. Rosyjscy naukowcy mogą się też ubiegać o stypendia polskiego rządu dla młodych badaczy z państw poradzieckich - jest to program prowadzony od 2003 r. przez Studium Europy Wschodniej UW. W 2020 r. stypendium uzyskało 9 naukowców z Rosji, spośród których 2 będą realizować projekty dotyczące relacji polsko-rosyjskich $^{32}$. Ponadto w latach 2011-2020 Narodowe Centrum Nauki sfinansowało w sferze nauk społecznych ok. 40 kierowanych przez polskich badaczy projektów dotyczących Rosji, w tym 3 w zakresie stosunków polsko-rosyjskich $^{33}$. W Rosji natomiast możliwości uzyskania środków przez naukowców z Polski i na badania o Polsce (w tym o relacjach dwustronnych) są bardziej ograniczone. Zasadniczo nie ma tam programów stypendialnych dla badaczy z Polski. Wśród grantów przyznawanych przez prezydenta Rosji młodym uczonym od 2006 r. znalazły się jedynie 2 projekty poświęcone relacjom polsko-rosyjskim (w tym 1 o charakterze historycznym) ${ }^{34}$. Międzynarodowe przedsięwzięcia badawcze $\mathrm{z}$ udziałem polskich naukowców i krótkookresowe wyjazdy rosyjskich badaczy do Polski (ale przede wszystkim w obszarze nauk ścisłych i przyrodniczych) wspiera za to Rosyjska Fundacja Badań

31 Stypendia / 7 edycja / 2018/2019, „Centrum Polsko-Rosyjskiego Dialogu i Porozumienia" [online, dostęp: 31 VII 2020]: <http://cprdip.pl/konkursy,stypendia,7_edycja_ 2018_2019.html>.

32 Informacje uzyskane przez autora w Studium Europy Wschodniej Uniwersytetu Warszawskiego.

33 Projekty finansowane przez NCN, „Narodowe Centrum Nauki” [online, dostęp: 31 VII 2020]: <https://projekty.ncn.gov.pl/index.php?jednostka=\&jednostka_miasto=\&jednos tka_wojewodztwo=\&kierownik=\&kierownik_plec=\&kierownik_tytul=\&status= \&projekt $=\&$ kwotaprzyznanaod $=\&$ kwotaprzyznanado $=\&$ typkonkursu $=\&$ konkurs $=$ \&grupa $=$ HS\&panel=\&slowokluczowe $=$ Rosja\&aparatura $=>$.

34 „Sovet po grantam Prezidenta Rossijskoj Federacii dlâ gosudarstvennoj podderžki molodyh rossijskih učenyh i po gosudarstvennoj podderžke veduŝih naučnyh škol Rossijskoj Federacii" [online, dostęp: 31 VII 2020]: 〈https://grants.extech.ru/〉. 
Podstawowych ${ }^{35}$. Relatywnie niewielką rolę odgrywają natomiast programy europejskie. Z wyjazdów w ramach Marie Skłodowska-Curie Actions skorzystało 8 naukowców z obu krajów ${ }^{36}$. Rosyjscy badacze są natomiast zaangażowani w projekty realizowane $\mathrm{w}$ ramach programu Horizon 2020, choć sama Rosja jako państwo nie jest jego partnerem ${ }^{37}$. Młodzi naukowcy z obu krajów (przede wszystkim doktoranci) mogą ponadto korzystać ze stypendiów przyznawanych przez poszczególne uczelnie w Polsce i Rosji.

Ostatni czynnik, na który trzeba zwrócić uwagę, to uwarunkowania polityczne. W latach 2008-2010 zainicjowano próbę resetu stosunków polsko-rosyjskich. Jego efektem była m.in. przygotowana przez Polsko-Rosyjską Grupę ds. Trudnych wspólna publikacja Białe plamy, czarne plamy. Sprawy trudne $w$ relacjach polsko-rosyjskich (1918-2008)38. W latach 2011-2012 powołano Centrum Polsko-Rosyjskiego Dialogu i Porozumienia oraz jego rosyjski odpowiednik - Rosyjsko-Polskie Centrum Dialogu i Porozumienia. Po rosyjskiej agresji przeciwko Ukrainie w 2014 r. współpraca między obiema instytucjami uległa jednak ograniczeniu ${ }^{39}$. Podobnie rzecz się miała w sferze współpracy akademickiej, przynajmniej w przypadku Uniwersytetu Warszawskiego ${ }^{40}$. Istotną rolę odgrywa również sytuacja wewnątrzpolityczna, zwłaszcza w Rosji.

35 Zob. rezultaty wyszukiwania hasła Польша w: Poisk, „Rossijskij fond fundamental'nyh issledovanij" [online, dostęp: 31 VII 2020]: 〈https://www.rfbr.ru/rffi/ru/search/? query $=\% \mathrm{EF} \% \mathrm{EE} \% \mathrm{~EB} \% \mathrm{FC} \% \mathrm{~F} \% \%$ Eo\&start_date=\&end_date=\&object_type_id=-1 $>$.

36 H2O2O - Marie Skłodowska-Curie Actions (MSCA). Country fact sheet: Russian Federation $(R U)$, European Commission, 25 XI 2020: $<$ https://ec.europa.eu/research/mariecurieactions/sites/mariecurie2/files/third_countries_o.zip〉 [dostęp: 29 XI 2020].

37 Por. Horizon 2020 country profiles, „European Commission” [online, dostęp: 31 VII 2020]: 〈https://ec.europa.eu/research/horizon2020/index.cfm?pg=country-profiles .

38 Białe plamy, czarne plamy... Książka ukazała się również w Rosji: Belye pâtna, černye pâtna: složnye voprosy $v$ rossijsko-pol'skih otnošeniâh, red. A. V. Torkunov, A. D. Rotfel'd, Izdatel'stvo „Aspekt Press”, Moskva 2010.

39 Centrum Polsko-Rosyjskiego Dialogu i Porozumienia. Sprawozdanie z działalności w roku 2015, Centrum Polsko-Rosyjskiego Dialogu i Porozumienia, [b.d.m.w.], s. 5: <http:// cprdip.pl/assets/media/O_Nas/Sprawozdanie_z_dzialalnosci_Centrum_Polsko_ Rosyjskiego_Dialogu_i_Porozumienia_za_rok_2015.pdf> [dostęp: 1 VIII 2020].

40 W szczególności spadła liczba studentów i doktorantów z Rosji. Ograniczono również liczbę umów o współpracy międzyuczelnianej zawieranych ze szkołami wyższymi w Rosji. Por. Sprawozdania roczne rektora UW, „Uniwersytet Warszawski" [online, dostęp: 1 VIII 2020]: <https://www.uw.edu.pl/uniwersytet/ sprawozdania-roczne-rektora-uw/>. 
Tamtejsze uczelnie są podatne na wpływy polityczne ${ }^{41}$, a władze dążą do ograniczenia niezależnej działalności badawczej i edukacyjnej. Dobrym przykładem są tu działania wymierzone w stowarzyszenie Memoriał, które zajmuje się badaniem m.in. zbrodni katyńskiej ${ }^{42}$. Również niektórzy polscy badacze uskarżają się, że obiektywne zgłłębianie relacji polsko-rosyjskich nie jest łatwe, gdyż „zyskuje się miano niebezpiecznego stronnika Rosji [i] "agenta wpływu" " ${ }^{\text {" }}$. Ta uwaga odnosi się również mutatis mutandis do przyjaciół Polski w Rosji.

\section{Ogólna charakterystyka}

Badania nad współczesnymi relacjami polsko-rosyjskimi i ich wybranymi aspektami daleko wykraczają poza naukę o stosunkach międzynarodowych. W ciągu minionych trzech dekad problematykę tę podejmowali również inni politolodzy, prawnicy, ekonomiści, socjolodzy, historycy, geografowie, etnografowie, filolodzy czy specjaliści w zakresie nauk o bezpieczeństwie oraz mediów i komunikacji.

Specyfiką analizowanego obszaru jest różnorodność dostępnej literatury. Obok prac naukowych: monografii jednoautorskich, opracowań zbiorowych, artykułów i rozdziałów w pracach zbiorowych istotną rolę odgrywają publikacje o charakterze popularnonaukowym, publicystycznym, eksperckim i dziennikarskim. Niekiedy nawet trudno jednoznacznie odróżnić teksty naukowe od opracowań $\mathrm{z}$ innych wspomnianych wyżej kategorii ${ }^{44}$.

41 J. Butterfield, E. Levintova, Academic freedom and international standards in higher education: Contestation in journalism and political science at Moscow State University, "Communist and Post-Communist Studies" 2011, vol. 44, No. 4, s. 329-341.

42 Zob. np. K. Chawryło, M. Domańska, Obcy wśród swoich. Organizacje pozarządowe $w$ Rosji, Ośrodek Studiów Wschodnich, [Warszawa] 28 IX 2015 (Komentarze OsW, 184): 〈https://www.osw.waw.pl/sites/default/files/komentarze_184.pdf〉 [dostęp: 1 VIII 2020].

43 Pamięć $i$ polityka historyczna $w$ stosunkach polsko-rosyjskich, red. S. Bieleń, A. Skrzypek, Oficyna Wydawnicza „ASPRA-JR”, Warszawa 2017.

44 Istotnym kryterium jest obecność w bazie Scopus, na liście czasopism punktowanych polskiego Ministerstwa Nauki i Szkolnictwa Wyższego lub w Rosyjskim Indeksie Cytowania Naukowego (RINC). 
Jako publikacje popularnonaukowe należy traktować teksty przygotowane przez naukowców, a skierowane do odbiorców spoza tego grona - zredagowane w przystępnej formie, często bez rozbudowanego aparatu naukowego $^{45}$. Wiarygodność tego typu materiałów opiera się przede wszystkim na renomie autora, a możliwość wykorzystania ich jako literatury w pracy badawczej pozostaje kwestią indywidualnej oceny ${ }^{46}$.

Publicystyka może dotyczyć zarówno spraw bieżących, jak i bardziej uniwersalnych; ważną cechą jest w tym przypadku subiektywizm, tj. mocne akcentowanie stanowiska autora $\mathrm{w}$ omawianej kwestii ${ }^{47}$. Działalnością publicystyczną w omawianym obszarze parają się naukowcy (zarówno zajmujący się Rosją i stosunkami polsko-rosyjskimi ${ }^{48}$, jak i prowadzący badania $w$ innych obszarach ${ }^{49}$ ), ale także pisarze ${ }^{50}$ czy zawodowi publicyści $^{51}$. Na gruncie badawczym wykorzystanie twórczości publicystycznej jako literatury przedmiotu - zwłaszcza jeśli jej autor nie legitymizuje się odpowiednią wiedzą - budzi pewne wątpliwości. Można natomiast uznać publicystykę za swego rodzaju materiał źródłowy.

Publikacje eksperckie mają charakter zarówno analityczny, jak i prognostyczny. Dotyczą z reguły zagadnień aktualnych i istotnych z perspektywy danego państwa lub społeczeństwa. Są swoistym ogniwem pośrednim między światem polityki a światem nauki. Ich obiektywizm może budzić wątpliwości z powodu zaangażowania określonych ośrodków

45 Por. Encyklopedia książki, t. 2, red. A. Żbikowska-Migoń, M. Skalska-Zlat, Wydawnictwo Uniwersytetu Wrocławskiego, Wrocław 2017, s. 165-167.

46 Zob. np.: W. Marciniak, Dwie tendencje w polityce polskiej wobec Rosji, „Arcana. Kultura, historia, polityka" 2010, nr 4 (94), s. 66-71; G. F. Matveev, Pol'sko-rossijskie otnošeniâ v XX veke glazami nepredvzâtogo istorika, „Istoričeskaâ èkspertiza” 2019, № 2 (19), s. 70-74.

47 Z. Bauer, Gatunki dziennikarskie, [w:] Dziennikarstwo i świat mediów, red. Z. Bauer, E. Chudziński, Universitas, Kraków 2010, s. 269-274.

48 B. Łagowski, Polska chora na Rosję, Wydawnictwo „Fundacja Oratio Recta”, Wrocław 2016.

49 Z. Najder, Patrzac na Wschód, Kolegium Europy Wschodniej im. Jana Nowaka-Jeziorańskiego, Wrocław 2008.

50 J. Pomianowski, Na wschód od zachodu. Jak być z Rosją?, Rosner \& Wspólnicy, Warszawa 2004.

51 I. V. Pyhalov, Pol'ša. Giena Vostočnoj Evropy, Izdatel'skij dom „Piter”, Sankt-Peterburg 2019. 
eksperckich w spory polityczne lub ideologiczne ${ }^{52}$. Publikacje eksperckie ukazują się $\mathrm{w}$ formie książe ${ }^{53}$, artykułów ${ }^{54}$ lub raportów dostępnych $\mathrm{w}$ internecie ${ }^{55}$.

Ostatnią kategorią, na którą należy zwrócić uwagę, są książkowe publikacje dziennikarskie, w szczególności o charakterze śledczym. Podejmują one zagadnienia ważne i interesujące z perspektywy czytelników, dążąc do przedstawienia nieznanych opinii publicznej wydarzeń i procesów, zwłaszcza nadużyć, przestępstw czy skandali ${ }^{56}$. W Polsce ukazało się $\mathrm{w}$ ostatnich latach kilka istotnych tekstów z tego gatunku dotyczących nielegalnego importu węgla $\mathrm{z}$ kontrolowanego przez prorosyjskich separatystów Donbasu ${ }^{57}$, ingerencji Rosji w wydarzenia polityczne w Polsce (tzw. afery taśmowej ${ }^{58}$ ) lub powiązań określonych środowisk politycznych z Federacją Rosyjską ${ }^{59}$.

Analizując poświęcone relacjom polsko-rosyjskim publikacje o charakterze stricte naukowym, trzeba zwrócić uwagę na ich zróżnicowany poziom. Obok dogłębnych monografii, przemyślanych pod względem układu prac zbiorowych czy artykułów opublikowanych w renomowanych czasopismach naukowych część przeanalizowanych publikacji budzi zastrzeżenia.

52 T.de Montbrial, Działanie i system świata, Wydawnictwo Akademickie „Dialog”, Warszawa 2011, s. 158.

53 Polska i Rosja. Strategoiczne sprzeczności i możliwości dialogu, red. A. Magdziak-Miszewska, Centrum Stosunków Międzynarodowych, Więź, Warszawa 1998.

54 E. Wyciszkiewicz, Polska wobec Rosji. Mniej znaczy więcej, „Sprawy Międzynarodowe” 2018, t. 71, nr 3, s. 43-50; Û. Solozobov, Otvet na "pol'skij vopros”, „Političeskij klass” 2009, № 9 (57), s. 38-49.

55 K. Pełczyńska-Nałęcz, Jak uniknąć rozmów ponad naszymi głowami? Polska wobec Rosji $w$ dobie konfrontacji, Fundacja im. Stefana Batorego, Warszawa 2016: <https://www. batory.org.pl/upload/files/Programy\%20operacyjne/Otwarta\%2oEuropa/Polska\%20 wobec\%20Rosji \%20-\%20K\%20Pelczynska-Nacz.pdf> [dostęp: 3 VIII 2020].

56 T. Sasińska-Klas, Dziennikarstwo - zawód czy wyzwanie, [w:] Dziennikarstwo i świat mediów..., s. 473, 476.

57 K. Baca-Pogorzelska, M. Potocki, Czarne złoto. Wojny o wegiel z Donbasu, Wydawnictwo „Czarne”, Wołowiec 2020.

58 G. Rzeczkowski, Obcym alfabetem. Jak ludzie Kremla i Pis zagrali podsłuchami, Wydawnictwo „Arbitror”, Warszawa 2019.

59 T. Piątek, Macierewicz i jego tajemnice, Wydawnictwo „Arbitror”, Warszawa 2017. 
Niektóre opracowania zbiorowe, mimo przywoływania w tytułach Polski i Rosji, jedynie w niewielkim stopniu podejmują problematykę dwustronnych relacji czy nawet analizę porównawczą obu państw ${ }^{60}$. Istotną słabością części rosyjskich prac naukowych jest powierzchowność. Przeanalizowane artykuły opublikowane w Rosji liczą średnio ok. 10 stron, polskie - ok. 15, a zachodnie - ok. 18. Również niektóre publikacje książkowe mają charakter raczej broszur niż solidnych opracowań monograficznych ${ }^{61}$. Kolejne zjawisko to powielanie tekstów na ten sam temat lub zagadnienia do siebie zbliżone. Jeszcze innym problemem jest niska cytowalność zidentyfikowanych publikacji: tylko 110 spośród 487 zostało zindeksowanych w bazie Scopus, z czego zaledwie 65 miało wskaźnik cytowań większy od zera. Wśród publikacji najwyżej cytowanych znalazły się m.in. prace Tomasza Zaryckiego, Mathiasa Rotha, George'a Sanforda czy Stanisława Domaniewskiego i Dominiki Studzińskiej.

\section{Główne ośrodki badawcze}

Badania dotyczące relacji polsko-rosyjskich prowadzone są przede wszystkim przez naukowców z polskich ośrodków i publikowane w Polsce. Relatywnie mniejszym zainteresowaniem zagadnienie to cieszy się $\mathrm{w}$ Rosji. Warto odnotować niską liczbę 46 pozycji, w których znajdziemy nazwiska badaczy zarówno z Polski, jak i Rosji, co zbiega się z poczynioną wcześniej obserwacją, że współpraca naukowa środowisk z obu krajów ma w tym obszarze charakter ograniczony (zob. wykres 1). Statystykę tę poprawia nieco fakt, że niektórzy polscy autorzy publikują w Rosji, a rosyjscy - w Polsce (36 tekstów). Poza tym badania relacji polsko-rosyjskich prowadzone były przez naukowców z państw zachodnich, m.in. Stanów Zjednoczonych, Kanady, Wielkiej Brytanii, Francji, Niemiec i Szwecji, a także z Turcji oraz Europy Środkowej i Wschodniej: Litwy, Rumunii i Ukrainy.

60 Zob. np. Polska - Rosja. Współczesny świat. Zintegrowany czy zdezintegrowany?, red. M. Kaszuba, M. Stempień, M. Niedbała, Oficyna Wydawnicza „Rytm”, Warszawa 2018.

61 Zob. np. 73-stronicową publikację: Perspektivy evropejskoj integracii v XXI veke. Rol' Pol'śi i Rossii, red. D. V. Kacy, Sankt-Peterburgskij gosudarstvennyj universitet, Sankt-Peterburg 2002. 
według miejsca wydania

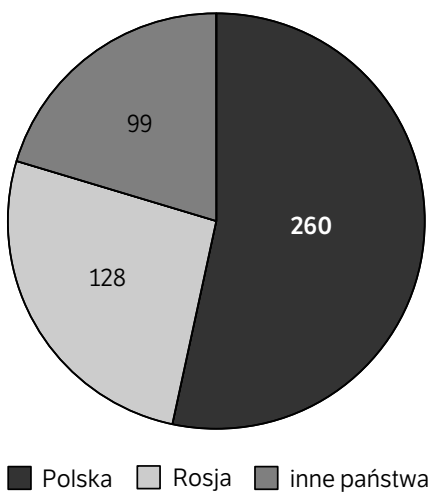

według miejsca zatrudnienia autorów

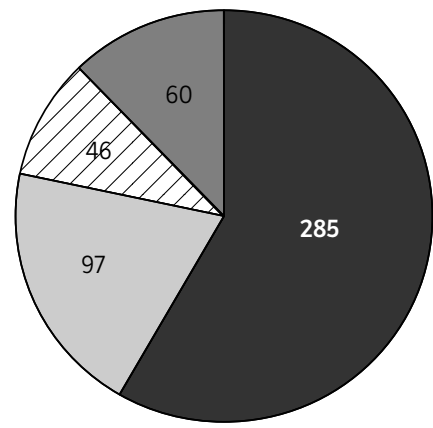

Polska $\square$ Rosja $\square$ Polska i Rosja $\square$ inne państwa

Wykres 1. Analizowane publikacje według miejsca wydania i zatrudnienia autorów Źródło: oprac. własne

Wśród polskich ośrodków badawczych na uwagę zasługują cztery placówki akademickie. Naukowcy współtworzący Katedrę Studiów Wschodnich Uniwersytetu Warszawskiego (Stanisław Bieleń, Ryszard Zięba i Maciej Raś) poświęcili wiele uwagi stosunkom między Polską i Rosją, polskiej polityce wschodniej, a także zagadnieniu pamięci i pojednania $\mathrm{w}$ relacjach dwustronnych. Ważną rolę w badaniu polityki Polski wobec obwodu kaliningradzkiego i polsko-rosyjskiej współpracy transgranicznej odgrywają Zakład Rozwoju Regionalnego Uniwersytetu Gdańskiego (Tadeusz Palmowski i Renata Anisiewicz) oraz Katedra Nauk o Polityce i Nauk o Bezpieczeństwie Uniwersytetu Warmińsko-Mazurskiego w Olsztynie (Arkadiusz Żukowski, Marcin Chełminiak, Wojciech Kotowicz, Wojciech T. Modzelewski i Krzysztof Żęgota). Szereg prac poświęconych Polsce i Rosji opublikował Zespół Badań Strategicznych Wymiarów Bezpieczeństwa Międzynarodowego Uniwersytetu Przyrodniczo-Humanistycznego w Siedlcach. Dwustronnymi relacjami polsko-rosyjskimi zajmował się również istniejący w latach 2001-2018 Instytut Europy Środkowo-Wschodniej w Lublinie.

Polski Instytut Spraw Międzynarodowych zrealizował przed piętnastu laty projekt badawczy dotyczący wzajemnych uprzedzeń między Polakami a Rosjanami ${ }^{62}$. Opublikowano tam również kilka znaczących pozycji

62 Katalog wzajemnych uprzedzeń Polaków i Rosjan, red. A. de Lazari, Polski Instytut Spraw Międzynarodowych, Warszawa 2006; Polacy i Rosjanie - przezwyciężanie uprzedzeń, red. A. de Lazari, T. Rogozińska, Polski Instytut Spraw Międzynarodowych, Warszawa 2006. 
zewnętrznych autorów w zakresie współczesnych relacji polsko-rosyjskich ${ }^{63}$, a periodyczne analizy na ten temat publikowane były na łamach „Rocznika Polskiej Polityki Zagranicznej" ${ }^{\prime 64}$. Centrum Polsko-Rosyjskiego Dialogu i Porozumienia opublikowało z kolei kilka wartościowych prac dotyczących historii relacji polsko-rosyjskich ${ }^{65}$, natomiast jeśli chodzi o kwestie współczesne, to jego aktywność ograniczała się do opracowań o charakterze analitycznym.

Oprócz działalności wspomnianych ośrodków na uwagę zasługują prace pojedynczych autorów, takich jak Adam Daniel Rotfeld (Wydział „Artes Liberales” Uniwersytetu Warszawskiego), Andrzej Nowak (Instytut Historii Polskiej Akademii Nauk, Zakład Historii Europy Wschodniej Uniwersytetu Jagiellońskiego), Mieczysław Stolarczyk, Rafał Lisiakiewicz czy wspomniani już Dominika Studzińska i Tomasz Zarycki.

W głównych ośrodkach akademickich w Rosji nie ma zespołów badawczych, które w sposób zorganizowany zajmowałyby się stosunkami polsko-rosyjskimi. W Moskwie istotną rolę odgrywają w tym obszarze historycy, szczególnie ci badający zbrodnię katyńską, zarówno w kontekście historycznym, jak i współczesnym. Z tego grona wymienić trzeba Iniessę Jażborowską (Instytut Socjologii Rosyjskiej Akademii Nauk), Natalję Lebiediewą (Instytut Historii RAN), a także nieżyjących już Nikołaja Bucharina (Instytut Międzynarodowych Studiów Ekonomicznych i Politycznych RAN, Instytut Ekonomii RAN) i Łarisę Łykoszynę (Instytut Słowianoznawstwa RAN). Wśród moskiewskich politologów relacjami z Polską zajmowała się Natalja Łapina. Pewną rolę odgrywają również autorzy związani z różnymi organizacjami, jak Nikita Pietrow z Memoriału.

Badania na temat stosunków polsko-rosyjskich prowadzone są również w Petersburskim Uniwersytecie Państwowym, zarówno na Wydziale Stosunków Międzynarodowych (Igor Griecki i Natalja Zasławska), jak i w innych jednostkach (Jewgienij Wapilin). Ważnym ośrodkiem, który wspólnie z partnerami z Polski prowadzi badania dotyczące współpracy transgranicznej i regionalnej, jest Bałtycki Uniwersytet Federalny im. Immanuela

63 Białe plamy, czarne plamy...; A. Nowak, History and geopolitics: a contest for Eastern Europe, Polski Instytut Spraw Międzynarodowych, Warszawa 20o8; Dusza polska i rosyjska...

64 Zob. np. A. Legucka, Polityka Polski wobec Rosji, „Rocznik Polskiej Polityki Zagranicznej" 2017, s. 128-142.

65 Myślą i słowem...; Wbrew królewskim aliansom... 
Kanta w Kaliningradzie, a w szczególności Instytut Zasobów Środowiska, Rozwoju Terytorialnego i Planowania Miejskiego (Giennadij Fiodorow i Iwan Gumieniuk) oraz Instytut Rekreacji, Turystyki i Wychowania Fizycznego (Walentin Korniejewiec i Natalja Zajcewa). W latach 1997-2012 nakładem Instytutu Międzynarodowych Studiów Politycznych i Ekonomicznych RAN (następnie Instytutu Ekonomii RAN) ukazała się seria książek poświęconych relacjom Rosji z państwami Europy Środkowej, w tym z Polską.

Rosyjsko-Polskie Centrum Dialogu i Porozumienia nie prowadzi natomiast badań nad współczesnymi stosunkami polsko-rosyjskimi. Wspiera jednak działalność wydawniczą, m.in. w zakresie historii dwustronnych relacji po rozpadzie $\mathrm{ZSRR}^{66}$, polskiej i rosyjskiej historiografii ${ }^{67} \mathrm{czy}_{\mathrm{dwu}}$ stronnych kontaktów kulturalnych ${ }^{68}$.

\section{Główne obszary badań}

Pod względem tematycznym badania poświęcone współczesnym stosunkom polsko-rosyjskim można podzielić na dziewięć zasadniczych obszarów. Pomijając uwarunkowania, połowa z nich (relacje polityczne, gospodarcze i społeczne oraz stosunki w sferze bezpieczeństwa) odpowiada podstawowym dziedzinom stosunków międzynarodowych analizowanych w literaturze naukowej, a połowa dotyczy specyficznych zagadnień istotnych z perspektywy relacji dwustronnych (granicy i obwodu kaliningradzkiego, pamięci i pojednania, relacji między Polską, Rosją i Unią Europejską oraz stosunków polsko-rosyjskich w obszarze wspólnego sąsiedztwa).

Istotną część literatury na temat uwarunkowań relacji pomiędzy Polską a Rosją sensu largo stanowią publikacje ukazujące oba państwa z perspektywy badań porównawczych. Zasadniczo nie podejmują one kwestii stosunków dwustronnych, niemniej pozwalają lepiej zrozumieć różnice (rzadziej: podobieństwa) pomiędzy Polską a Federacją Rosyjską. Badacze polscy, rosyjscy i zachodni chętnie zajmowali się kwestią wartości politycznych.

66 N. I. Buharin, Rossiâ-Pol'ša. Opyt dvadcatiletnih otnošenij. 90-e gody XX veka - pervoe desâtiletie XXI veka, Nestor-Istoriâ, Moskva 2014.

67 Rossiâ v pol'skoj istoriografii, Pol'ša v rossijskoj istoriografii (k 50-letiû Komissii istorikov Rossii i Pol'ši), red. N. A. Makarov, Indrik, Moskva 2017.

68 G. Višnevskij, Meždu Pol'šej i Rossiej - Igor' i Svâtoslav Bèlza, Izdatel' Stepanenko, Moskva 2018. 
a relatywnie mniejszym zainteresowaniem cieszyły się badania dotyczące tożsamości w Polsce i Rosji, przemian elit czy gospodarki. Na Zachodzie podejmowano również badania dotyczące różnych aspektów transformacji w obu krajach. Niektóre z nich ukazywały w tym kontekście Polskę jako przykład pozytywny, a Rosję - jako negatywny; inne wskazywały na słabość przemian w obu krajach. Należy odnotować fakt, że część wspomnianych publikacji dotyczących badań porównawczych była zdecydowanie bardziej poczytna od innych analizowanych tekstów ${ }^{69}$.

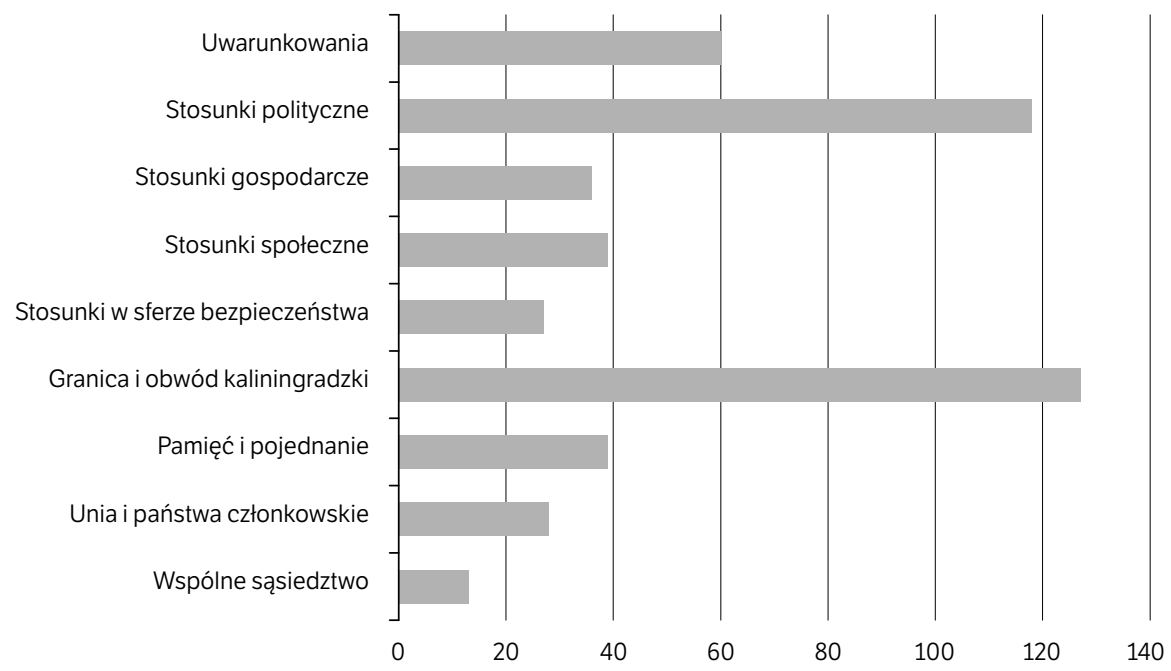

Wykres 2. Analizowane publikacje według obszarów badań

Źródło: oprac. własne

Drugą znaczącą kategorią publikacji na temat uwarunkowań relacji polsko-rosyjskich są te, które podejmują kwestie obustronnej percepcji. W tym kontekście analizowano wzajemne postrzeganie się przez oba społeczeństwa i określone grupy społeczne czy prezentowanie ich w literaturze i mediach. Na uwagę zasługuje tu praca Mariusza Maszkiewicza, który

69 P. Murell, What is shock therapy? What did it do in Poland and Russia?, "Post-Soviet Affairs" 1993, vol. 9, No. 2, s. 111-140 (154 cytowania w Scopusie); L. King, Postcommunist divergence: A comparative analysis of the transition to capitalism in Poland and Russia, "Studies in Comparative International Development" 2002, vol. 37, No. 3, s. 3-34 (53 cytowania); G. M. Easter, Politics of revenue extraction in post-communist states: Poland and Russia compared, „Politics \& Society” 2002, vol. 30, No. 4, s. 599-627 (43 cytowania). 
dokonał szczegółowej analizy recepcji polskiej polityki w Rosji, a także na Ukrainie i Białorusi ${ }^{70}$. Istotną grupę stanowią teksty dotyczące stereotypów i uprzedzeń dzielących Polaków i Rosjan. Część autorów wskazywała w tym kontekście na istniejącą ich zdaniem w Polsce rusofobię ${ }^{71}$, związaną m.in. z faktem, że Polska jest granicznym krajem zachodniego (katolickiego) świata, a także z nacjonalistyczną polityką Prawa i Sprawiedliwości. Należy odnotować, że o ile kwestia wzajemnej percepcji w kontekście historyczno-kulturowym jest opisana relatywnie dobrze, o tyle odczuwa się niedostatek dogłębnych prac socjologicznych na temat wzajemnego postrzegania się obu społeczeństw obecnie. Tego typu dociekania wymagają współpracy zespołów badawczych z obu państw i znaczących nakładów finansowych.

Przedmiotem badań były ponadto koncepcje determinujące wzajemną politykę obu państw, przy czym publikacje te dotyczą przede wszystkim polityki Polski. Klasyczną już pozycją w tym obszarze jest Testament Prometeusza Pawła Kowala ${ }^{72}$. Analizowano również stanowisko polskich sił politycznych wobec Rosji, a szczególnym zainteresowaniem badaczy cieszyła się w tym kontekście polska prawica.

Ostatnia kategoria zasługująca na uwagę to publikacje na temat uwarunkowań historycznych. Nie chodzi w tym przypadku o prace dotyczące pamięci historycznej, o której będzie jeszcze mowa, ale raczej o teksty, które opierają się na mniej lub bardziej explicite sformułowanym założeniu, że przeszłe relacje

70 Wspomniany autor uważa, że Polska jest w Rosji mało widoczna, jej koncepcje są nierozumiane lub nieznane, a ponadto często prezentowane w sposób wykrzywiony i tendencyjny. M. Maszkiewicz, Między bezpieczeństwem a tożsamościa. Rosyjskie, ukraińskie i białoruskie interpretacje idei i koncepcji $w$ polskiej polityce wschodniej (1990-2010), Kolegium Europy Wschodniej im. Jana Nowaka-Jeziorańskiego, Wrocław 2013, s. 521-522.

71 R. Taras, Russia resurgent, Russophobia in decline? Polish perceptions of relations with the Russian Federation 2004-2012, „Europe-Asia Studies” 2014, vol. 66, No. 5 , s. 710-734; T. Zarycki, Uses of Russia: The role of Russia in the modern Polish national identity, „East European Politics and Societies” 2004, vol. 18, No. 4, s. 595-627. Problematyką tą zajmował się również w swoich felietonach Bronisław Łagowski: B. Łagowski, Polska...

72 P. Kowal, Testament Prometeusza. Źródła polityki wschodniej III Rzeczypospolitej, Instytut Studiów Politycznych PAN, Kolegium Europy Wschodniej im. Jana Nowaka-Jeziorańskiego, Warszawa-Wojnowice 2018. Kowal do źródeł polityki wschodniej III RP zaliczył m.in. koncepcje prometejskie, dorobek paryskiej „Kultury”, ale również politykę Jana Pawła II wobec bloku wschodniego. 
polsko-radzieckie oraz polsko-rosyjskie tworzą pewne continuum, że charakter i specyfika stosunków dwustronnych wynika z historii. Wśród publikacji poświęconych tej tematyce na uwagę zasługują prace Andrzeja Nowaka ${ }^{73}$.

Stosunki polityczne mają charakter nadrzędny nad innymi dziedzinami stosunków międzynarodowych, co wynika z prymatu państw w tego rodzaju relacjach. Ponieważ jednak nie ma czystej polityki, obejmują one również inne dziedziny stosunków międzynarodowych będące przedmiotem zainteresowania państw. W Polsce $\mathrm{w}$ ciągu ostatnich trzydziestu lat ukazało się kilkanaście książek poświęconych relacjom politycznym między Polską a Rosją. Większość z nich opublikowano przed rewolucją godności na Ukrainie i wybuchem ukraińsko-rosyjskiej wojny w 2014 r., co sprawia, że nie uwzględniają części istotnych obecnie zagadnień. Po tych wydarzeniach ukazało się kilka prac zbiorowych, m.in. pod redakcją Mirosława Minkiny i Maliny Kaszuby ${ }^{74}$ oraz Roberta Białoskórskiego i Beaty Gałek ${ }^{75}$; listę tę uzupełnia monografia autorstwa Mieczysława Stolarczyka dotycząca polityki Polski wobec Rosji w latach $1992-2015^{76}$. W Rosji publikacje dotyczące wzajemnych relacji były relatywnie mniej liczne. W krajach zachodnich przed dekadą ukazała się jedna książka dotycząca tej tematyki - autorstwa Joanny A. Gorskiej ${ }^{77}$. Podsumowując, należy stwierdzić, że

73 Nowak interpretuje stosunki polsko-rosyjskie przez pryzmat pojęcia imperium i koncepcji imperialnych obu państw - zarówno Polski w przeszłości (Rzeczypospolitej Obojga Narodów, II RP), jak i Rosji (Imperium Rosyjskiego, ZSRR, Federacji Rosyjskiej). Zob. w szczególności: Rosja i Europa Wschodnia: „imperiologia” stosowana, red. A. Nowak, Wydawnictwo „Arcana”, Kraków 2006; A. Nowak, History and geopolitics...

74 M. Minkina, M. Kaszuba, Polska - Rosja: perspektywa sąsiedzka, Pracownia Wydawnicza Wydziału Humanistycznego Uniwersytetu Przyrodniczo-Humanistycznego, Siedlce 2015 .

75 Polska - Rosja. Wektory współpracy, red. R. Białoskórski, B. Gałek, Pracownia Wydawnicza Wydziału Humanistycznego Uniwersytetu Przyrodniczo-Humanistycznego, Siedlce 2017 .

76 M. Stolarczyk, Rosja w polityce zagranicznej Polski, Wydawnictwo Uniwersytetu Śląskiego, Katowice 2016.

77 J.A. Gorska, Dealing with a Juggernaut. Analyzing Poland's policy toward Russia, 1989-2009, Lexington Books, Lanham 2010. Gorska utrzymuje, że w okresie 19892009 Polska prowadziła wobec Rosji politykę kooperacyjną, co wynikało z umocnienia jej pozycji po wejściu do UE i NATO oraz relatywnie niewielkiego zagrożenia ze strony wschodniego sąsiada. 
poza książką Stolarczyka, który podejmuje kwestię wydarzeń na Ukrainie w ich początkowej fazie, na rynku nie ma kompleksowej jednoautorskiej monografii, która ukazywałaby współczesny stan stosunków politycznych pomiędzy Polską a Federacją Rosyjską.

Ciekawe spostrzeżenia przynosi analiza artykułów naukowych, gdyż ta część rynku wydawniczego jest bardziej dynamiczna, a zatem szybciej reaguje na bieżące wydarzenia. Dobrze widać tam ewolucję dwustronnych relacji w ciągu minionych trzydziestu lat (wykres 3). W ostatniej dekadzie XX w. publikacje poświęcone stosunkom polsko-rosyjskim miały przede wszystkim charakter przeglądowy: pewnym wyjątkiem była debata na temat wpływu przyszłego poszerzenia Sojuszu na wschód na relacje Polski, Rosji i NATo. Stosunki dwustronne zyskały na znaczeniu wraz z wejściem Polski do Unii Europejskiej, o czym będzie jeszcze mowa przy okazji analizy stanu badań dotyczących relacji Polski, Rosji i Wspólnoty. Drugim ważnym wydarzeniem jest dojście do władzy w Polsce Platformy Obywatelskiej w 2007 r. i objęcie urzędu prezydenta Rosji przez Dmitrija Miedwiediewa w 2008, co zaowocowało próbą resetu dwustronnych relacji. Zainteresowanie problematyką stosunków polsko-rosyjskich w istotnym stopniu wzrosło wśród badaczy po katastrofie smoleńskiej w $2010 \mathrm{r}$. Ostatnim punktem zwrotnym była natomiast agresja Federacji Rosyjskiej przeciwko Ukrainie w 2014 r., która zakończyła politykę resetu i zaowocowała znaczącym pogorszeniem dwustronnych relacji politycznych.

Stosunki gospodarcze ze szczególnym uwzględnieniem wymiany handlowej doczekały się dwu kompleksowych opracowań pod redakcją Pawła Bożyka $^{78}$; z powodu daty wydania oba jednak po części się już zdezaktualizowały. Współczesne badania w tym obszarze skupiają się na trzech kwestiach. Pierwszą jest wymiana handlowa jako taka - przedmiot zainteresowania badaczy stanowią tu w szczególności konkurencyjność polskich produktów na rynkach Rosji i innych państw regionu, wpływ wejścia Polski do UE na wzajemną wymianę handlową i wreszcie konsekwencje sankcji wprowadzonych w tym obszarze w 2014 r. Druga to eksport polskich produktów rolno-spożywczych do Rosji - podejmowany często w publi-

78 Stosunki gospodarcze Polska-Rosja w warunkach integracji z Unią Europejska, red. P. Bożyk, Szkoła Główna Handlowa, Warszawa 2004; Polska - Rosja. Stosunki gospodarcze 2000-2020, red. P. Bożyk, Wyższa Szkoła Ekonomiczno-Informatyczna w Warszawie, Warszawa 2009. 


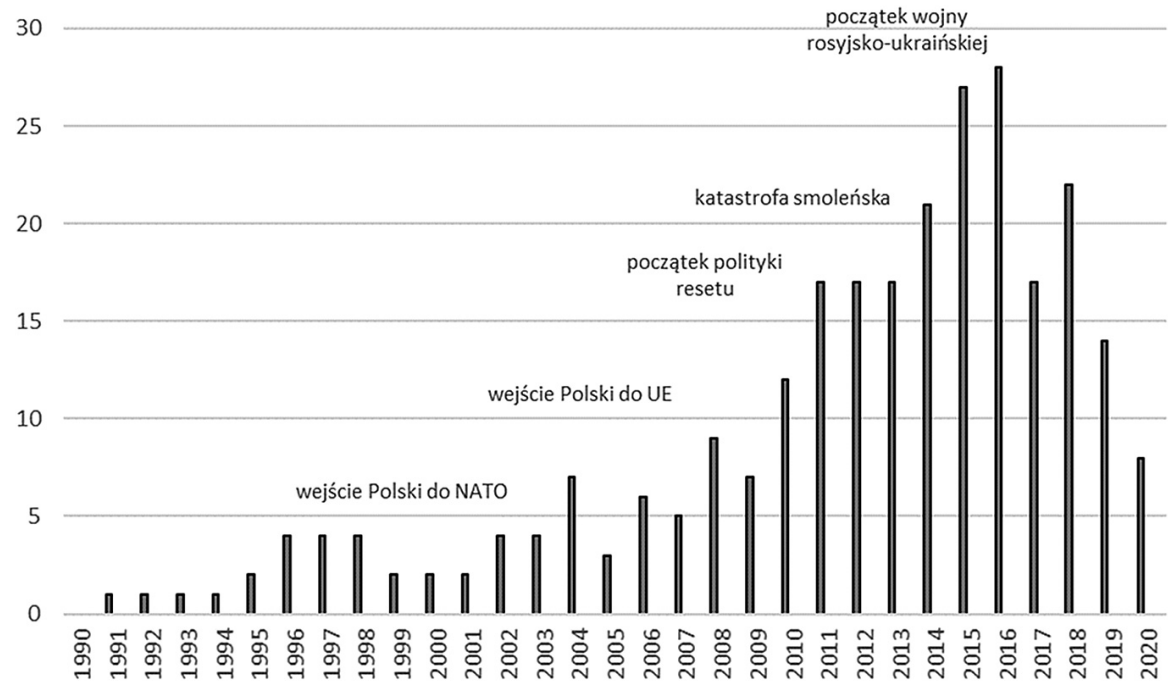

Wykres 3. Artykuły naukowe dotyczące relacji polsko-rosyjskich (1990-2020)

Źródło: oprac. własne

kacjach będących efektem badań prowadzonych na uczelniach rolniczych. Znaczenie tej problematyki wzrosło po wybuchu wojny rosyjsko-ukraińskiej, co wynika z faktu, że polski sektor rolno-spożywczy poniósł negatywne konsekwencje ograniczenia wymiany handlowej pomiędzy Rosją a UE. Kwestia trzecia dotyczy wreszcie stosunków między Polską a Rosją w sferze energetycznej. Wśród badaczy podejmujących kwestie energetyczne w relacjach polsko-rosyjskich znaczącą rolę odgrywali naukowcy z państw zachodnich. W ostatnim okresie szczególnym zainteresowaniem cieszyły się projekt budowy gazociągu Nord Stream 2 i jego konsekwencje dla Polski. Mniejsze znaczenie mają z perspektywy badawczej powiązania transportowe między Polską a Rosją czy dość ograniczona współpraca inwestycyjna.

Polsko-rosyjskie stosunki społeczne są zdaniem Marcina Dębickiego i Julii Makaro w stanie katastrofalnym, m.in. za sprawą uwarunkowań politycznych ${ }^{79}$. Mimo to istnieje bogata literatura, która ukazuje zarówno zróżnicowanie relacji społecznych, jak występujące w tym obszarze trudności. Przedmiotem analiz były zwłaszcza wzajemna percepcja obu społeczeństw, współpraca w sferze nauki i oświaty, różne formy kontaktów

79 M. Dębicki, J. Makaro, Wprowadzenie, [w:] Sąsiedztwa III RP - Rosja. Zagadnienia społeczne, red. M. Dębicki, J. Makaro, Wydawnictwo „Gajt”, Wrocław 2016, s. 8-38. 
kulturalnych (nauczanie języka, kinematografia, muzyka klasyczna, literatura, dyplomacja kulturalna) czy mniejszości etniczne - Polacy w Rosji i Rosjanie w Polsce. W bardziej ograniczonym zakresie zajmowano się natomiast relacjami międzykonfesyjnymi czy rolą sportu w stosunkach polsko-rosyjskich (meczem Polska - Rosja podczas Euro $2012^{80}$ ).

Publikacje poświęcone stosunkom w sferze bezpieczeństwa można podzielić na cztery kategorie. Autorzy polscy podejmują przede wszystkim kwestię współzależności pomiędzy polityką Rosji i bezpieczeństwem Polski. Problematyka ta zyskała na znaczeniu zwłaszcza po 2014 r., co zaowocowało nowymi tekstami na temat ewentualnego zagrożenia, jakim może być dla kraju Federacja Rosyjska. Niektórzy wojskowi przestrzegają przed wojną ze wschodnim sąsiadem i jej niekorzystnym dla Polski wynikiem $^{81}$. Naukowcy zdają się w tej kwestii bardziej wstrzemięźliwi. Rafał Kopeć i Przemysław Mazur stwierdzają, że konfliktu z Rosją wykluczyć się nie da, ale zalecają, by „nie ulegać propagandzie opartej na partykularnych interesach politycznych czy prostych fobiach" ${ }^{\text {"2 }}$. W tym kontekście niektórzy autorzy zwracają uwagę na zagrożenie wojny hybrydowej. W ograniczonym zakresie analizowano również instrumenty wpływu (polityczne, informacyjne itp.), jakimi dysponuje w Polsce Rosja i jakie mogłyby zostać wykorzystane $\mathrm{w}$ takim nietradycyjnym konflikcie. Druga grupa publikacji dotyczy odmiennych wizji bezpieczeństwa europejskiego, jakie prezentują Polska (wzmocnienie roli NATO w Europie Środkowej, poszerzenie Sojuszu Północnoatlantyckiego i UE na wschód) i Rosja (agresja przeciwko Ukrainie, militaryzacja obwodu kaliningradzkiego, propozycja nowego ładu europejskiego). Trzecia grupa tekstów podejmuje kwestię relacji w trójkącie Polska - NATO - Rosja. W latach dziewięćdziesiątych najważniejszym zagadnieniem był sprzeciw Moskwy wobec przyjmowania do Sojuszu nowych członków. Gdy już jednak to nastąpiło, rosyjskich autorów interesowały przede wszystkim relacje Rosji z nowymi sygnatariuszami Paktu, a polskich - zwłaszcza od wybuchu wojny na Ukrainie - wiarygodność gwa-

80 M. J. Kozon, Derby of a "difficult" history: the Poland-Russia match at Euro 2012, "Soccer and Society" 2018, vol. 19, No. 5-6, s. 745-765.

81 J. Ćwieluch, M. Różański, Dlaczego przegramy wojnę z Rosją, Wydawnictwo "Znak”, Kraków 2018.

82 R. Kopeć, P. Mazur, Odstraszanie militarne w XXI wieku. Polska - NATO - Rosja, Uniwersytet Pedagogiczny im. Komisji Edukacji Narodowej, Kraków 2017, s. 150. 
rancji bezpieczeństwa ze strony NATO. Ostatni temat, który budzi zainteresowanie, to relacje między Polską, Rosją i Stanami Zjednoczonymi, zwłaszcza w kontekście projektu tarczy antyrakietowej i roli UsA w uniezależnieniu Polski od dostaw rosyjskiego gazu.

Granica polsko-rosyjska - i szerzej: sąsiedztwo Polski z obwodem kaliningradzkim - to problematyka najliczniejszej z grup, jakie można wydzielić spośród analizowanych publikacji. Wynika to przede wszystkim z dużej aktywności Uniwersytetu Warmińsko-Mazurskiego, Uniwersytetu Gdańskiego i Bałtyckiego Uniwersytetu Federalnego im. Immanuela Kanta w Kaliningradzie. Poza dwiema publikacjami pod redakcją Arkadiusza Żukowskiego, które mają charakter przeglądowy ${ }^{83}$, w badaniach tych poruszano sześć zagadnień. Najliczniejszą grupę stanowią teksty dotyczące współpracy transgranicznej pomiędzy północno-wschodnią Polską a obwodem kaliningradzkim: w szczególności turystycznej, między polskimi portami bałtyckimi a Kaliningradem oraz w ramach Euroregionu Bałtyk, którego uczestnikami są obwód kaliningradzki oraz województwa pomorskie i warmińsko-mazurskie. Ponadto poruszane są w nich uwarunkowania tej współpracy związane z polityką Polski i Rosji czy członkostwem Polski w Unii Europejskiej.

Druga grupa publikacji opisuje zagadnienie sąsiedztwa Polski z obwodem kaliningradzkim przez pryzmat związanych z tym wyzwań i zagrożeń. W eksklawie tej zgromadzone są znaczące siły zbrojne, w tym wyrzutnie rakiet średniego i dalekiego zasięgu, które mogą być uzbrojone w głowice atomowe. Znaczenie tej kwestii wzrosło po rosyjskiej agresji przeciwko Ukrainie w 2014 r., pojawiły się bowiem obawy, że znajdujący się w obwodzie kaliningradzkim potencjał militarny może być wykorzystany jako instrument nacisku na Polskę i inne państwa bałtyckie.

Trzeci obszar badawczy zasługujący na uwagę to kwestia przepływu osób przez polsko-rosyjską granicę. Po przystąpieniu Polski do UE w 2004 r. i strefy Schengen w 2007 granica polsko-rosyjska stała się granicą zewnętrzną Wspólnoty, a ruch osobowy uległ ograniczeniu. W 2012 r. weszła w życie umowa o małym ruchu granicznym, która objęła cały obwód kaliningradzki oraz określone powiaty województw warmińsko-mazurskiego

83 Polska wobec Obwodu Kaliningradzkiego Federacji Rosyjskiej, red. A.Żukowski, Instytut Nauk Politycznych Uniwersytetu Warmińsko-Mazurskiego, Olsztyn 2004; Polska a Obwód Kaliningradzki Federacji Rosyjskiej, red. A. Żukowski, Wydawnictwo „Adam Marszałek", Toruń 2008. 
i pomorskiego. Mieszkańcy tej strefy podróżujący między oboma krajami zostali zwolnieni z obowiązku posiadania wiz. Mały ruch graniczny generował korzyści związane z rozwojem gospodarczym miasta przygranicznego, ale jednocześnie sprzyjał negatywnemu zjawisku przemytu. Po wybuchu wojny rosyjsko-ukraińskiej Polska zawiesiła stosowanie umowy, co przyczyniło się do ograniczenia dwustronnych kontaktów.

Znaczącą rolę w bilateralnych relacjach Polski z Rosją - i to zarówno na płaszczyźnie badawczej, jak i politycznej - odgrywa pamięć historyczna. Świadczy o tym w szczególności fakt, że właśnie tej problematyce poświęciła swą pierwszą i jedyną publikację Polsko-Rosyjska Grupa ds. Trudnych. Oprócz prac o charakterze przeglądowym ${ }^{84}$ badania w tym obszarze obejmują cztery zasadnicze kwestie. Pierwszą jest postrzeganie przez polską i rosyjską historiografię wspólnej przeszłości lub jej określonych okresów. Druga to zbrodnia katyńska, jej współczesna ocena i wpływ na relacje polsko-rosyjskie. Zagadnieniu temu poświęcono najwięcej publikacji w obszarze pamięci historycznej: Iniessa Jażborowskaja stawia wręcz hipotezę, że zbrodnia katyńska jest najważniejszym problemem dwustronnych relacji ${ }^{85}$. Przedmiotem analiz były tu w szczególności polityka Rosji (zwłaszcza działania mające na celu stopniowe zdjęcie odpowiedzialności za zbrodnię z władz ZSRR) i w mniejszym zakresie Polski, a także losy sprawy katyńskiej przed Europejskim Trybunałem Praw Człowieka. Trzecie zagadnienie będące przedmiotem zainteresowania badaczy to obecny w Polsce syndrom martyrologii, którego ważnym - choć nie jedynym - symbolem w relacjach z Rosją jest właśnie zbrodnia katyńska. Na uwagę zasługują tu zwłaszcza prace Tomasza Zaryckiego ${ }^{86}$. Ostatnia kwestia z tego obszaru, na którą trzeba zwrócić uwagę,

84 Pamięć i polityka historyczna...

85 I. Âžborovskaâ, Katynskij sindrom - klûčevaâ problema dvustoronnih otnošenij?, „Sensus Historiae" 2013, vol. 10, No. 1, s. 131-145.

86 Zarycki dochodzi do wniosku, że polska trauma historyczna jest pewnego rodzaju konstruktem społecznym, a pozytywne elementy rosyjskiego dziedzictwa w Polsce są przez tę ostatnią ignorowane. Zob. T.Zarycki, T. Warczok, The social construction of historical traumas: The Polish experience of the uses of history in an intelligentsia-dominated polity, „European Review” 2020, vol. 28, No. 6: <https://doi. org/10.1017/S1062798720000344> [dostęp: 15 III 2021]; T.Zarycki, The embarrassing Russian connection. Selective memory of the Russian heritage in contemporary Poland, [w:] Russia's identity in international relations. Images, perceptions, misperceptions, ed. R. Taras, Routledge, Abingdon-New York 2013, s. 133-148. 
to proces polsko-rosyjskiego pojednania ${ }^{87} \mathrm{i}$ jego perspektywy. Większość tekstów poświęconych temu zagadnieniu powstała $\mathrm{w}$ pierwszej połowie minionej dekady, gdy w następstwie polityki resetu i tragedii smoleńskiej pojednanie wydawało się możliwe. $\mathrm{Z}$ tego powodu tylko w ograniczonym zakresie podejmują one kwestię wpływu rosyjskiej agresji przeciwko Ukrainie z 2014 r. na proces polsko-rosyjskiego pojednania.

Badania dotyczące relacji w trójkącie Rosja - Polska - Unia Europejska i jej państwa członkowskie skupiają się na pięciu zagadnieniach. W przeszłości analizowano - przede wszystkim w Rosji - ewentualne negatywne konsekwencje przystąpienia Polski do UE dla Federacji Rosyjskiej. W późniejszym okresie najważniejszym zagadnieniem była kwestia polityki Polski i Unii wobec Rosji oraz wpływ Warszawy na politykę wschodnią Wspólnoty ${ }^{88}$. W tym kontekście przedmiotem szczególnego zainteresowania jest polityka energetyczna UE i rola, jaką odgrywa w niej Polska. Zarówno polscy, jak i rosyjscy badacze szczegółowo analizowali również relacje w trójkącie Polska - Rosja - Niemcy. W tym kontekście badano możliwości polsko-niemieckiej współpracy wobec Rosji, związane z tym wyzwania, rolę Polski w relacjach rosyjsko-niemieckich („most czy mur"), konsekwencje, jakie niesie dla niej położenie pomiędzy Rosją a Niemcami, i wreszcie możliwości współpracy tych trzech państw. Ostatnie zagadnienie, które było przedmiotem badań, to stosunki Rosji z państwami Europy Środkowej. Naukowcy z tego regionu zgodnie zwracają uwagę na narastające rozbieżności pomiędzy nowymi państwami członkowskimi UE i NATO w ich polityce wobec Rosji, za punkt zwrotny uważając rok 2014. Polska zaliczana jest do zwolenników nowej zimnej wojny, podczas gdy Węgry i Słowacja - do bardziej przychylnych Rosji pragmatyków.

Publikacje poświęcone stosunkom Polski, Rosji i państw wspólnego sąsiedztwa są relatywnie najmniej liczne. Badania dotyczące tej problematyki skupiają się przede wszystkim na Ukrainie. Przedmiotem

87 Rzadziej pisano w tym kontekście o zaufaniu. Por. A. Włodkowska-Bagan, Trust in Polish-Russian relations. Is it possible?, „The Copernicus Journal of Political Studies” 2015, No. 7 (1), s. 37-47.

88 Na uwagę zasługują tu m.in. publikacje powstałe w ramach projektu „Europa i jej sąsiedzi” realizowanego w Centrum Europejskim „Natolin”, np. P. Żurawski vel Grajewski, Polityka Unii Europejskiej wobec Rosji a interesy Polski 1991-2004, Ośrodek Myśli Politycznej, Kraków 2008. 
analiz były relacje $\mathrm{w}$ trójkącie Polska - Rosja - Ukraina widziane zarówno z perspektywy dwu pierwszych państw, jak i Kijowa. Znaczenie tego zagadnienia wzrosło po rosyjskiej agresji przeciwko Ukrainie. Wśród publikacji dotyczących innych państw i całego regionu na uwagę zasługują teksty analizujące stanowisko Polski wobec wojny rosyjsko-gruzińskiej z 2008 r., podejście Rosji do polsko-szwedzkiej inicjatywy Partnerstwa Wschodniego, a także zaangażowanie Warszawy w proces przemian w państwach Europy Wschodniej i Kaukazu Południowego. W tym kontekście istotna jest zwłaszcza publikacja Eksport riewolucyi. Juszczenko, Saakaszwili... ${ }^{89}$

\section{Perspektywy}

Analiza stanu badań nad współczesnymi stosunkami polsko-rosyjskimi pozwala stwierdzić, że jest to tematyka, którą w ciągu minionych trzech dekad podejmowali przedstawiciele różnych dziedzin nauk społecznych zarówno w Polsce i Rosji, jak też na Zachodzie. Jednocześnie brakuje publikacji, które przedstawiałyby ją w sposób kompleksowy i aktualny. Wynika to zarówno ze złożonego charakteru wzajemnych relacji i ich dużej dynamiki, jak też z selektywnego podejścia badaczy.

Kolejna kwestia to potrzeba szerszego rozwinięcia teoretycznej podstawy badań, przynajmniej tych, które prowadzi się w obszarze nauki o stosunkach międzynarodowych. Pewne próby w tym zakresie były już podejmowane - trzeba przywołać w szczególności prace Adrianny Dudek ${ }^{90}$, Walentiny Fekluniny ${ }^{91}$, Stanisława Bielenia i Andrzeja Skrzypka ${ }^{92}$, Siergieja Bucharina

89 S. Kara-Murza, Èksport revolûcii. Ûŝenko, Saakašvili.., Algoritm, Moskva 2005. Główną tezą publikacji jest to, że polska Solidarność była swego rodzaju archetypem kolorowych rewolucji zainicjowanych na obszarze poradzieckim przez Stany Zjednoczone, które - m.in. przy wsparciu Polski - dążyły w ten sposób do ograniczenia wpływów Rosji w regionie.

90 A. Dudek, Poland and Russia at the turn of XXI century. Between a liberal illusion and imperial realism, „UNISCI Discussion Papers” 2016, No. 40, s. 77-100.

91 V. Feklyunina, Russia's foreign policy towards Poland: Seeking reconciliation? A social constructivist analysis, „International Politics” 2012, vol. 49, No. 4, s. 434-448.

92 Geopolityka w stosunkach polsko-rosyjskich, red. S. Bieleń, A. Skrzypek, Oficyna Wydawnicza „ASPRA-JR”, Warszawa 2012. 
i Nikołaja Rakitianskiego ${ }^{93}$ czy Andrzeja Nowaka ${ }^{94}$. Wciąż jednak większość tekstów poświęconych relacjom polsko-rosyjskim, zwłaszcza w sferze politycznej, pozbawiona jest aparatu teoretycznego. To o tyle zaskakująca sytuacja, że omawiana problematyka daje szerokie pole do interpretacji teoretycznej $\mathrm{z}$ wykorzystaniem różnych paradyǵmatów badawczych ${ }^{95}$ : realizmu (antagonizm polsko-rosyjski jako konflikt interesów), konstruktywizmu (antagonizm polsko-rosyjski jako konflikt wartości i tożsamości) ${ }^{96}$ czy instytucjonalizmu (antagonizm polsko-rosyjski a członkostwo Polski w UE).

Studia nad relacjami polsko-rosyjskimi wymagają większej internacjonalizacji, i to zarówno na etapie badań (powinny być prowadzone przez zespoły mieszane), jak i publikacji ich wyników. Obecnie większość prac ma charakter wsobny: autorzy polscy piszą dla czytelników polskich, a rosyjscy - dla rosyjskich. Paradoksalnie najbardziej poczytne prace poświęcone Polsce i Rosji - choć trudno przesądzać a priori, czy najlepsze - ukazują się w krajach zachodnich. W tym kontekście na pozytywną ocenę zasługuje fakt, że niektóre czasopisma zajmujące się stosunkami Polski i Rosji (np. „Rocznik Polskiej Polityki Zagranicznej” czy wydawany przez Bałtycki Uniwersytet Federalny im. Immanuela Kanta „Bałtijskij riegion”) ukazują się $\mathrm{w}$ również $\mathrm{w}$ wersji angielskiej.

Na pogłębioną analizę zasługują z pewnością niektóre idées fixes obecne w literaturze przedmiotu, np. imperialny charakter współczesnej polityki Rosji i wynikające stąd zagrożenia dla Polski czy polska rusofobia, choć ten ostatni problem został już częściowo zbadany przez specjalistów zajmujących się polską pamięcią historyczną. Na większą uwagę ze strony badaczy zasługuje również część zagadnień, którymi na razie zajmują się przede wszystkim eksperci i dziennikarze - w szczególności rosyjska wojna hybrydowa i to, czy Polska jest lub może być jej celem, a także możliwa ingerencji Rosji w życie polityczne w Polsce po 2014 r.

93 S. N. Buharin, N. M. Rakitânskij, Rossiâ i Pol'ša. Opyt politiko-psihologičeskogo issledovaniâ fenomena limitrofizacii, Institut russkoj civilizacii, Moskva 2011.

94 Rosja i Europa Wschodnia...; A. Nowak, History...

95 Por. A. Dudek, Użyteczność analitycznego eklektyzmu w badaniu stosunków Polski $z$ Rosja, "Stosunki Międzynarodowe” 2016, t. 52, nr 2, s. 39-70.

96 Szerzej zob. A. Szeptycki, Poland versus Russia: competition in Ukraine, „East European Politics and Societies" 2020: 〈https://doi.org/10.1177\%2Fo888325420950803> [dostęp: 15 III 2021]. 
Warte uwagi są wreszcie same badania nad stosunkami polsko-rosyjskimi. Współpraca naukowa Polski i Rosji stanowi ciekawy przypadek dwu peryferyjnych czy półperyferyjnych krajów, które tylko w ograniczonym stopniu zdolne są wspólnie eksplorować potencjalnie interesujące obszary badań. Wynika to zarówno z uwarunkowań politycznych, jak również z niedostatku środków finansowych i braku atrakcyjnych instrumentów sprzyjających prowadzeniu badań i upowszechnianiu ich rezultatów (np. wysokopunktowanych czasopism).

Wiele ze wspomnianych wyżej problemów dotyczy też zapewne innych obszarów badań prowadzonych w ramach nauk społecznych w Polsce, Rosji i większości krajów spoza grupy najwyżej rozwiniętych. Ekstrapolacja tych trendów wykracza jednak poza ramy niniejszego tekstu i powinna być przedmiotem odrębnych dociekań.

\section{Bibliografia}

Âžborovskaâ I., Katynskij sindrom - klûčevâa problema dvustoronnih otnošenij?, "Sensus Historiae" 2013, vol. 10, No. 1.

Baca-Pogorzelska K., Potocki M., Czarne złoto. Wojny o węgiel z Donbasu, Wydawnictwo "Czarne", Wołowiec 2020.

Bauer Z., Gatunki dziennikarskie, [w:] Dziennikarstwo i świat mediów, red. Z. Bauer, E. Chudziński, Universitas, Kraków 2010.

Bazylow L., Wieczorkiewicz P., Historia Rosji, Zakład Narodowy im. Ossolińskich, Wrocław-Warszawa-Kraków 2005.

Belye pâtna, černye pâtna: složnye voprosy v rossijsko-pol'skih otnošeniâh, red. A. V. Torkunov, A. D. Rotfel'd, Izdatel'stvo „Aspekt Press", Moskva 2010.

Biate plamy, czarne plamy. Sprawy trudne w relacjach polsko-rosyjskich (1918-2008), red. A. D. Rotfeld, A. W. Torkunow, Polski Instytut Spraw Międzynarodowych, Warszawa 2010.

Bruski J. J., Między prometeizmem a Realpolitik. II Rzeczpospolita wobec Ukrainy Sowieckiej 1921-1926, Historia Iagellonica, Kraków 2010.

Bryc A., Rosja w XXI wieku. Gracz światowy czy koniec gry?, Wydawnictwa Akademickie i Profesjonalne, Warszawa 2008.

Buharin N. I., Rossiâ-Pol'ša. Opyt dvadcatiletnih otnošenij. 9o-e gody XX veka - pervoe desâtiletie XXI veka, Nestor-Istoriâ, Moskva 2014.

Buharin S. N., Rakitânskij N. M., Rossiâ i Pol'ša. Opyt politiko-psihologičeskogogo issledovaniâ fenomena limitrofizacii, Institut russkoj civilizacii, Moskva 2011.

Butterfield J., Levintova E., Academic freedom and international standards in higher education: Contestation in journalism and political science at Moscow State University, "Communist and Post-Communist Studies” 2011, vol. 44, No. 4. 
Centrum Polsko-Rosyjskiego Dialogu i Porozumienia. Sprawozdanie z działalności $w$ roku 2015, Centrum Polsko-Rosyjskiego Dialogu i Porozumienia, [b.d.m.w.]: <http:// cprdip.pl/assets/media/O_Nas/Sprawozdanie_z_dzialalnosci_Centrum_Polsko_ Rosyjskiego_Dialogu_i_Porozumienia_za_rok_2015.pdf> [dostęp: 1 VIII 2020]. Chawryło K., Domańska M., Obcy wśród swoich. Organizacje pozarządowe w Rosji, Ośrodek Studiów Wschodnich, [Warszawa] 28 IX 2015 (Komentarze OsW, 184): <https://www.osw.waw.pl/sites/default/files/komentarze_184.pdf> [dostęp: 1 VIII 2020].

Chodubski A. J., Wstęp do badań politologicznych, Wydawnictwo Uniwersytetu Gdańskiego, Gdańsk 2004.

Country Rankings, „Scimago Journal \& Country Rank” [online], kwiecień 2020 [dostęp: 31 VII 2020]: <https:/www.scimagojr.com/countryrank. php?category $=3320>$.

Czaputowicz J., Ławniczak K., Wojciuk A., Nauka o stosunkach międzynarodowych $i$ studia europejskie w Polsce, Wydawnictwo Naukowe "Scholar”, Warszawa 2015. Ćwieluch J., Różański M., Dlaczego przegramy wojnę z Rosją, Wydawnictwo "Znak”, Kraków 2018.

Dębicki M., Makaro J., Wprowadzenie, [w:] Sąsiedztwa III RP - Rosja. Zagadnienia społeczne, red. M. Dębicki, J. Makaro, Wydawnictwo „Gajt”, Wrocław 2016.

Donaldson R. H., Nogee J. L., The foreign policy of Russia. Changing systems, enduring interests, M. E. Sharpe, London-Armonk 2005.

Dudek A., Poland and Russia at the turn of XXI century. Between a liberal illusion and imperial realism, „UNISCI Discussion Papers” 2016, No. 40.

Dudek A., Użyteczność analitycznego eklektyzmu w badaniu stosunków Polski z Rosją, „Stosunki Międzynarodowe” 2016, t. 52, nr 2.

Dusza polska i rosyjska. Od Adama Mickiewicza i Aleksandra Puszkina do Czesława Miłosza i Aleksandra Solżenicyna. Materiały do "katalogu” wzajemnych uprzedzeń Polaków i Rosjan, red. A. de Lazari, Polski Instytut Spraw Międzynarodowych, Warszawa 2004.

Dziennikarstwo i świat mediów, red. Z. Bauer, E. Chudziński, Universitas, Kraków 2010. Easter G. M., Politics of revenue extraction in post-communist states: Poland and Russia compared, „Politics \& Society” 2002, vol. 30, No. 4.

„EBSCO" [online, dostęp: 10 XII 2020]: 〈https://www.ebsco.com/>.

Encyklopedia książki, t. 2, red. A. Żbikowska-Migoń, M. Skalska-Zlat, Wydawnictwo Uniwersytetu Wrocławskiego, Wrocław 2017.

Enemies, „Levada-Center” [online], 5 XI 2020 [dostęp: 19 XI 2020]: <https://www. levada.ru/en/2020/11/05/enemies-2/>.

Feklyunina V., Russia's foreign policy towards Poland: Seeking reconciliation? A social constructivist analysis, „International Politics” 2012, vol. 49, No. 4.

Geopolityka w stosunkach polsko-rosyjskich, red. S. Bieleń, A. Skrzypek, Oficyna Wydawnicza „ASPRA-JR”, Warszawa 2012.

"Google Scholar" [online, dostęp: 10 XII 2020]: 〈https://scholar.google.com/>. 
Gorska J.A., Dealing with a Juggernaut. Analyzing Poland's policy toward Russia, 1989-2009, Lexington Books, Lanham 2010.

H2O2O - Marie Skłodowska-Curie Actions (MSCA). Country fact sheet: Russian Federation $(R U)$, European Commission, 25 XI 2020: <https://ec.europa.eu/research/mariecurieactions/sites/mariecurie2/files/third_countries_o.zip > [dostęp: 29 XI 2020].

Heller M., Polska w oczach Moskwy, Instytut Literacki, Paryż 1984.

Heller M., Niekricz A., Utopia u władzy. Historia Związku Sowieckiego, t. 1, Polonia Book Fund, London 1985.

Horizon 2020 country profiles, „European Commission” [online, dostęp: 31 VII 2020]: <https://ec.europa.eu/research/horizon2020/index.cfm?pg=country-profiles〉. Jażborowskaja I., Stan badań na temat stosunków polsko-radzieckich, [w:] Białe plamy, czarne plamy. Sprawy trudne $w$ relacjach polsko-rosyjskich (1918-2008), red. A. D. Rotfeld, A. W. Torkunow, Polski Instytut Spraw Międzynarodowych, Warszawa 2010.

Kara-Murza S., Èksport revolûcii. Ûŝenko, Saakašvili..., Algoritm, Moskva 2005.

Katalog wzajemnych uprzedzeń Polaków i Rosjan, red. A. de Lazari, Polski Instytut Spraw Międzynarodowych, Warszawa 2006.

King L., Postcommunist divergence: A comparative analysis of the transition to capitalism in Poland and Russia, "Studies in Comparative International Development” 2002, vol. 37, No. 3.

Kopeć R., Mazur P., Odstraszanie militarne w XXI wieku. Polska - NATO - Rosja, Uniwersytet Pedagogiczny im. Komisji Edukacji Narodowej, Kraków 2017.

Kornat M., Stan badań na temat stosunków polsko-radzieckich, [w:] Białe plamy, czarne plamy. Sprawy trudne w relacjach polsko-rosyjskich (1918-2008), red. A. D. Rotfeld,

A. W. Torkunow, Polski Instytut Spraw Międzynarodowych, Warszawa 2010.

Kowal P., Testament Prometeusza. Źródła polityki wschodniej III Rzeczypospolitej, Instytut Studiów Politycznych PAN, Kolegium Europy Wschodniej im. Jana Nowaka-Jeziorańskiego, Warszawa-Wojnowice 2018.

Kozon M. J., Derby of a "difficult" history: the Poland-Russia match at Euro 2012, "Soccer and Society" 2018, vol. 19, No. 5-6.

Kultura - Rosja, t. 1: Literatura rosyjska w kręgu „Kultury”, red. P. Mitzner, Instytut Literacki „Kultura”, Instytut Książki, Paryż-Kraków 2016.

Kultura - Rosja, t. 2: "Kultura” i emigracja rosyjska, red. P. Mitzner, Instytut Literacki „Kultura”, Instytut Książki, Paryż-Kraków 2016.

Legucka A., Polityka Polski wobec Rosji, „Rocznik Polskiej Polityki Zagranicznej” 2017.

Łagowski B., Polska chora na Rosję, Wydawnictwo „Fundacja Oratio Recta”, Wrocław 2016.

Łoś-Nowak T., Stosunki międzynarodowe. Teorie - systemy - uczestnicy, Wrocław 2000. Malak K., Czynnik wojskowy w polityce zagranicznej Federacji Rosyjskiej (1991-2000), Akademia Obrony Narodowej, Warszawa 2001.

Malgin A. W., Stosunki polityczne między Polska a Rosja po 1990 r., [w:] Białe plamy, czarne plamy. Sprawy trudne w relacjach polsko-rosyjskich (1918-2008), red. A. D. Rotfeld, A. W. Torkunow, Polski Instytut Spraw Międzynarodowych, Warszawa 2010. 
Marciniak W., Dwie tendencje w polityce polskiej wobec Rosji, „Arcana. Kultura, historia, polityka" 2010, nr 4 (94).

Maszkiewicz M., Między bezpieczeństwem a tożsamością. Rosyjskie, ukraińskie i białoruskie interpretacje idei i koncepcji w polskiej polityce wschodniej (1990-2010), Kolegium Europy Wschodniej im. Jana Nowaka-Jeziorańskiego, Wrocław 2013. Materski W., Historiografia stosunków polsko-radzieckich. Stan obecny i perspektywy badawcze, „Acta Universitatis Lodziensis. Folia Historica” 1996, nr 55.

Matveev G. F., Pol'sko-rossijskie otnošeniâ v XX veke glazami nepredvzâtogo istorika, „Istoričeskaâ èkspertiza” 2019, № 2 (19).

Minkina M., Kaszuba M., Polska - Rosja: perspektywa sasiedzka, Pracownia Wydawnicza Wydziału Humanistycznego Uniwersytetu Przyrodniczo-Humanistycznego, Siedlce 2015.

Mirovaâ politika i meždunarodnye otnošeniâ, red. Û. Kosov, Izdatel'skij dom „Piter”, Sankt-Peterburg 2011.

Montbrial T. de, Działanie i system świata, Wydawnictwo Akademickie "Dialog”, Warszawa 2011.

Murell P., What is shock therapy? What did it do in Poland and Russia?, „Post-Soviet Affairs" 1993, vol. 9, No. 2.

Najder Z., Patrząc na Wschód, Kolegium Europy Wschodniej im. Jana Nowaka-Jeziorańskiego, Wrocław 2008.

„Naučnaâ èlektronnaâ biblioteka" [online, dostęp: 10 XII 2020]: <https://www.eli brary.ru/defaultx.asp $>$.

Nowak A., History and geopolitics: a contest for Eastern Europe, Polski Instytut Spraw Międzynarodowych, Warszawa 2008.

Pamięć i polityka historyczna w stosunkach polsko-rosyjskich, red. S. Bieleń, A. Skrzypek, Oficyna Wydawnicza „ASPRA-JR”, Warszawa 2017.

Pełczyńska-Nałęcz K., Jak uniknąć rozmów ponad naszymi głowami? Polska wobec Rosji $w$ dobie konfrontacji, Fundacja im. Stefana Batorego, Warszawa 2016: <https://www.batory.org.pl/upload/files/Programy\%20operacyjne/Otwarta\%20 Europa/Polska\%20wobec\%20Rosji\%20-\%20K\%2OPelczynska-Nacz.pdf > [dostęp: 3 VIII 2020].

Pełczyńska-Nałęcz K., Stosunki polityczne między Polską a Rosją po 1990 r., [w:] Białe plamy, czarne plamy. Sprawy trudne w relacjach polsko-rosyjskich (1918-2008), red. A. D. Rotfeld, A. W. Torkunow, Polski Instytut Spraw Międzynarodowych, Warszawa 2010.

Perspektivy evropejskoj integracii v XXI veke. Rol' Pol'si i Rossii, red. D. V. Kacy, Sankt-Peterburgskij gosudarstvennyj universitet, Sankt-Peterburg 2002.

Piątek T., Macierewicz i jego tajemnice, Wydawnictwo „Arbitror”, Warszawa 2017. Pipes R., Polska sowietologia do 1939 roku, „Studia nad Autorytaryzmem i Totalitaryzmem" 2011, t. 33 .

Polacy i Rosjanie - przezwyciężanie uprzedzeń, red. A. de Lazari, T. Rogozińska, Polski Instytut Spraw Międzynarodowych, Warszawa 2006. 
Polityka zagraniczna Rosji, red. S. Bieleń, M. Raś, Wydawnictwo „Difin”, Warszawa 2008.

Polska a Obwód Kaliningradzki Federacji Rosyjskiej, red. A. Żukowski, Wydawnictwo „Adam Marszałek", Toruń 2008.

Polska i Rosja. Strategiczne sprzeczności i możliwości dialogu, red. A. Magdziak-Miszewska, Centrum Stosunków Międzynarodowych, Więź, Warszawa 1998.

Polska - Rosja. Stosunki gospodarcze 2000-2020, red. P. Bożyk, Wyższa Szkoła Ekonomiczno-Informatyczna w Warszawie, Warszawa 2009.

Polska - Rosja: traktat o przyjaznej i dobrosąsiedzkiej wspótpracy podpisany przez prezydentów Lecha Wałęsę i Borysa Jelcyna dnia 22 maja 1992 w Moskwie oraz inne dokumenty, Polski Instytut Spraw Międzynarodowych, Warszawa 1992.

Polska - Rosja. Wektory współpracy, red. R. Białoskórski, B. Gałek, Pracownia Wydawnicza Wydziału Humanistycznego Uniwersytetu Przyrodniczo-Humanistycznego, Siedlce 2017.

Polska - Rosja. Współczesny świat. Zintegrowany czy zdezintegrowany?, red. M. Kaszuba, M. Stempień, M. Niedbała, Oficyna Wydawnicza „Rytm”, Warszawa 2018.

Polska wobec Obwodu Kaliningradzkiego Federacji Rosyjskiej, red. A. Żukowski, Instytut Nauk Politycznych Uniwersytetu Warmińsko-Mazurskiego, Olsztyn 2004.

Pomianowski J., $\mathrm{Na}$ wschód od zachodu. Jak być z Rosją?, Rosner \& Wspólnicy, Warszawa 2004.

Popowska M., Internacjonalizacja uczelni wyższych na świecie i jej atrybuty a polska rzeczywistość, „Horyzonty Wychowania” 2016, t. 15, nr 35.

Projekty finansowane przez NCN, „Narodowe Centrum Nauki” [online, dostęp: 31 VII 2020]: <https://projekty.ncn.gov.pl/index.php?jednostka=\&jednostka_miasto= \&jednostka_wojewodztwo=\&kierownik=\&kierownik_plec=\&kierownik_tytul= \&status $=\&$ projekt $=\&$ kwotaprzyznanaod $=\&$ kwotaprzyznanado $=\&$ typkonkursu $=$ \&konkurs $=$ \&grupa $=$ Hs\&panel $=\&$ slowokluczowe $=$ Rosja\&aparatura $=>$.

Pyhalov I. V., Pol'ša. Giena Vostočnoj Evropy, Izdatel'skij dom „Piter”, Sankt-Peterburg 2019.

Research and development expenditure (\% of GDP), „The World Bank” [online, dostęp: 31 VII 2020]: <https://databank.worldbank.org/reports.aspx?source $=2 \&$ series $=$ GB.XPD.RSDV.GD.ZS\&country=>.

Rosja i Europa Wschodnia: „imperiologia” stosowana, red. A. Nowak, Wydawnictwo "Arcana”, Kraków 2006.

Rossiâ v pol'skoj istoriografii, Pol'ša v rossijskoj istoriografii (k 50-letiû Komissii istorikov Rossii i Pol'si), red. N. A. Makarov, Indrik, Moskva 2017.

"Rossijskij fond fundamental'nyh issledovanij" [online, dostęp: 31 VII 2020]: $<$ https://www.rfbr.ru/rffi/ru/search/?query=\%EF\%EE\%EB\%FC\%F $\%$ Eo\&start_ date $=$ \&end_date $=$ \&object_type_id $=-1>$.

Rousseau J. J., Uwagi nad rządem Polski, Krakowska Spółka Wydawnicza, Kraków 1924. Russia's identity in international relations. Images, perceptions, misperceptions, ed. R. Taras, Routledge, Abingdon-New York 2013. 
Rzeczkowski G., Obcym alfabetem. Jak ludzie Kremla i Pis zagrali podsłuchami, Wydawnictwo „Arbitror", Warszawa 2019.

Sadecki J., Bahr J., Ambasador, Warszawa 2013 (Biblioteka Gazety Wyborczej).

Samuś P., Wasza kartka wyborcza jest silniejsza niż karabin, niż armata. Z dziejów kultury politycznej na ziemiach polskich pod zaborami, Wydawnictwo Uniwersytetu Łódzkiego, Łódź 2013.

Sasińska-Klas T., Dziennikarstwo - zawód czy wyzwanie, [w:] Dziennikarstwo $i$ świat mediów, red. Z. Bauer, E. Chudziński, Universitas, Kraków 2010.

Sąsiedztwa III RP - Rosja. Zagadnienia społeczne, red. M. Dębicki, J. Makaro, Wydawnictwo „Gajt”, Wrocław 2016.

„Scopus" [online, dostęp: 10 XII 2020]: <https://www.scopus.com/search/form. uri?display=basic\#basic $>$.

Skrzypek A., Mechanizmy uzależnienia. Stosunki polsko-radzieckie 1944-1957, Wyższa Szkoła Humanistyczna im. Aleksandra Gieysztora, Pułtusk-Warszawa 2002. Solozobov Û., Otvet na „pol'skij vopros”, „Političeskij klass” 2009, № 9 (57).

„Sovet po grantam Prezidenta Rossijskoj Federacii dlâ gosudarstvennoj podderžki molodyh rossijskih učenyh i po gosudarstvennoj podderžke vedusîh naučnyh škol Rossijskoj Federacii" [online, dostęp: 31 VII 2020]: 〈https://grants.extech.ru/〉. Sprawozdania roczne rektora UW, „Uniwersytet Warszawski” [online, dostęp: 1 VIII 2020]: 〈https://www.uw.edu.pl/uniwersytet/sprawozdania-roczne-rektora-uw/ $>$. Staar R. F., Poland 1944-1962. The sovietization of a captive people, Louisiana State University Press, Baton Rouge 1962.

Stolarczyk M., Rosja w polityce zagranicznej Polski, Wydawnictwo Uniwersytetu Śląskiego, Katowice 2016.

Stosunki gospodarcze Polska-Rosja w warunkach integracji z Unia Europejska, red. P. Bożyk, Szkoła Główna Handlowa, Warszawa 2004.

Stypendia / 7 edycja / 2018/2019, "Centrum Polsko-Rosyjskiego Dialogu i Porozumienia" [online, dostęp: 31 VII 2020]: <http://cprdip.pl/konkursy,stypendia,7_ edycja_2018_2019.html>.

Šumilov M. M., Teoretičeskie osnovy mirovoj politiki i meždunarodnyh otnošenij, [w:] Mirovaâ politika i meždunarodnye otnošeniâ, red. Û. Kosov, Izdatel'skij dom „Piter”, Sankt-Peterburg 2011.

Szeptycki A., Poland versus Russia: competition in Ukraine, „East European Politics and Societies" 2020: 〈https://doi.org/10.1177\%2Fo888325420950803〉 [dostęp: 15 III 2021].

Szeptycki A., Stan badań nad współczesnymi stosunkami polsko-rosyjskimi, „Repozytorium Otwartych Danych" [online], 2 XII 2020 [dostęp: 3 XII 2020]: <https:// doi.org/10.18150/ICFU71>.

Taras R., Russia resurgent, Russophobia in decline? Polish perceptions of relations with the Russian Federation 2004-2012, „Europe-Asia Studies” 2014, vol. 66, No. 5. Topline questionnaire. Pew Research Center Spring 2019 Global Attitudes survey, Pew Research Center, 7 II 2020: <https://www.pewresearch.org/wp-content/ 
uploads/2020/o2/Views-of-Russia-Topline-for-Release_UPDATED.pdf> [dostęp: 19 XI 2020].

Višnevskij G., Meždu Pol'šej i Rossiej - Igor'i Svâtoslav Bèlza, Izdatel' Stepanenko, Moskva 2018.

Wbrew królewskim aliansom. Rosja, Europa i polska walka o niepodległtość w XIX w., red. Ł. Adamski, S. Dębski, Centrum Polsko-Rosyjskiego Dialogu i Porozumienia, Warszawa 2016.

Włodkowska-Bagan A., Trust in Polish-Russian relations. Is it possible?, „The Copernicus Journal of Political Studies" 2015, No. 7 (1).

Wschód $w$ globalnej $i$ regionalnej polityce międzynarodowej, red. A. Bartnicki, E. Kużelewska, Wydawnictwo „Adam Marszałek”, Toruń 2009.

Wyciszkiewicz E., Polska wobec Rosji. Mniej znaczy więcej, „Sprawy Międzynarodowe” 2018, t. 71, nr 3 .

Zarycki T., The embarrassing Russian connection. Selective memory of the Russian heritage in contemporary Poland, [w:] Russia's identity in international relations. Images, perceptions, misperceptions, ed. R. Taras, Routledge, Abingdon-New York 2013.

Zarycki T., Uses of Russia: The role of Russia in the modern Polish national identity, „East European Politics and Societies” 2004, vol. 18, No. 4.

Zarycki T., Warczok T., The social construction of historical traumas: The Polish experience of the uses of history in an intelligentsia-dominated polity, „European Review" 2020, vol. 28, No. 6: 〈https://doi.org/10.1017/S1062798720000344〉 [dostęp: 15 III 2021].

Żukowski A., Obwód Kaliningradzki Federacji Rosyjskiej jako przedmiot zainteresowania polskich badaczy stosunków międzynarodowych, [w:] Wschód w globalnej $i$ regiionalnej polityce międzynarodowej, red. A. Bartnicki, E. Kużelewska, Wydawnictwo „Adam Marszałek”, Toruń 2009.

Żurawski vel Grajewski P., Polityka Unii Europejskiej wobec Rosji a interesy Polski 1991-2004, Ośrodek Myśli Politycznej, Kraków 2008. 